$$
\begin{array}{ccccccc}
\text { L } & \text { E } & \text { T } & \text { u } & \text { v } & \text { O } & \text { s } \\
\hline \text { ARCHEOlogija } & 46
\end{array}
$$


Lietuvos istorijos institutas

\begin{tabular}{llllllll}
$\mathrm{L}$ & $\mathrm{I}$ & $\mathrm{E}$ & $\mathrm{T}$ & $\mathrm{U}$ & $\mathrm{V}$ & $\mathrm{O}$ & $\mathrm{S}$ \\
\hline
\end{tabular}

ARCHEOlogija 46 


\section{Leidybą finansavo}

\section{LIETUVOS MOKSLO TARYBA}

PAGAL VALSTYBINĘ LITUANISTINIŲ TYRIMŲ IR SKLAIDOS 2016-2024 METŲ PROGRAMĄ

(Finansavimo sutarties numeris S-LIP-19-4)

\section{Redaktorių kolegija / Editorial board:}

Atsakingoji redaktorė / Editor-in-chief dr. Agnè Čivilytė (Lietuvos istorijos institutas, Vilnius / Lithuanian Institute of History, Vilnius)

Atsakingosios redaktorès pavaduotoja / Assistant Editor dr. Elena Pranckènaitè (Lietuvos istorijos institutas, Vilnius / Lithuanian Institute of History, Vilnius)

Dr. Laurynas Kurila (Lietuvos istorijos institutas, Vilnius / Lithuanian Institute of History, Vilnius)

Dr. Valdis Bērziņš (Latvijos universitetas, Latvijos istorijos institutas, Ryga / University of Latvia, Institute of Latvian History, Riga)

Habil. dr. Anna Bitner-Wróblewska (Valstybinis archeologijos muziejus Varšuvoje, Lenkija / State Archaeological Museum in Warsaw, Poland)

Dr. Christoph Jahn (Baltijos ir Skandinavijos archeologijos centras, Šlèzvigas, Vokietija / Center for Baltic and Scandinavian Archaeology, Schleswig, Germany)

Prof. dr. Rimantas Jankauskas (Vilniaus universitetas, Lietuva / Vilnius University, Lithuania)

Akad. prof. dr. Eugenijus Jovaiša (Lietuvos mokslu akademija, Vilnius / Lithuanian Academy of Sciences, Vilnius)

Habil. dr. Bartosz Kontny (Varšuvos universitetas, Archeologijos fakultetas, Lenkija / Faculty of Archaeology, University of Warsaw, Poland)

Prof. dr. Valter Lang (Tartu universitetas, Estija / University of Tartu, Estonia)

Doc. dr. Algimantas Merkevičius (Vilniaus universitetas, Lietuva / Vilnius University, Lithuania)

Habil. dr. Tomasz Nowakiewicz (Varšuvos universitetas, Archeologijos fakultetas, Lenkija / Faculty of Archaeology, University of Warsaw, Poland)
Habil. dr. Grzegorz Osipowicz (Mikalojaus Koperniko universitetas, Torunè, Lenkija / Nicolaus Copernicus University, Toruń, Poland)

Dr. Gytis Piličiauskas (Lietuvos istorijos institutas, Vilnius / Lithuanian Institute of History, Vilnius)

Dr. Eve Rannamäe (Tartu universtitetas, Estija / University of Tartu, Estonia)

Dr. Andra Simniškyte (Lietuvos istorijos institutas, Vilnius / Lithuanian Institute of History, Vilnius)

Dr. Roberts Spirgis (Latvijos universitetas, Latvijos istorijos institutas, Ryga / University of Latvia, Institute of Latvian History, Riga)

Dr. Eugenijus Svetikas (Lietuvos istorijos institutas, Vilnius / Lithuanian Institute of History, Vilnius)

Dr. Andris Šnē (Latvijos universitetas, Ryga / University of Latvia, Riga)

Doc. dr. Gintautas Zabiela (Klaipédos universitetas, Lietuva / Klaipeda University, Lithuania)

Prof. dr. Šarūnas Milišauskas (Niujorko valstijos Bafalo universitetas, JAV / New York State University at Buffalo, USA)

Prof. dr. Timothy Chevral (Niujorko valstijos Bafalo universitetas, JAV / New York State University at Buffalo, USA)

Prof. dr. Johan Ling (Gioteborgo universitetas, Švedija / University of Gothenburg, Sweden)

Sekretorè / Secretary Dovilè Urbonavičiūtè-Jankauskienė

Redakcijos adresas / Editorial Board address:

Lietuvos istorijos institutas, Archeologijos skyrius

Kražių g. 5, LT-01108 Vilnius

Tel. (+370) 5 2614935, fax (+370) 52611433

e-mail: lietuvosarcheologija@gmail.com;

civilytea@gmail.com

\section{Žurnalas registruotas: EBSCO Publishing: Central and Eastern European Academic Source European Reference Index for the Humanities and Social Sciences (ERIH PLUS)}




\section{TURINYS / CONTENT}

Agnè Čivilytè

Agnè Čivilytè

Jonas Beran

Gabrielè Gudaitienè

Andreas Kotula, Henny Piezonka, Thomas Terberger

Vygandas Juodagalvis

Eglè Šatavičè

Grzegorz Osipowicz, Justyna Orłowska, Gytis Piličiauskas, Giedrẻ Piličiauskienė, Mariusz Bosiak

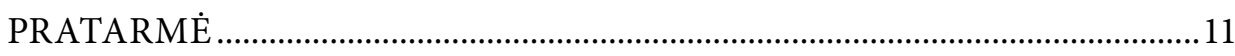

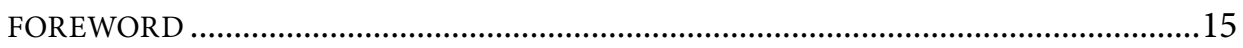

RUDENS POPIETĖ SU RIMUTE RIMANTIENE _.............................................19

AUTUMN AFTERNOON WITH RIMUTE் RIMANTIENĖ

GREETINGS FROM OLD CENTRAL-EASTERN GERMANY:

MEMORIES OF INTERESTING TIMES .27

LINKĖJIMAI IŠ PIETRYČIŲ VOKIETIJOS: PRISIMINIMAI APIE ĮDOMIUS LAIKUS

\section{STRAIPSNIAI / ARTICLES}

EIGULIAI, ONE OF RIMUTE் RIMANTIENĖ'S FIRST EXCAVATIONS A REVISED INTERPRETATION .33

EIGULIAI - VIENA PIRMŲJŲ RIMUTĖS RIMANTIENĖS KASINĖJIMŲ VIETŲ.

NAUJA INTERPRETACIJA

THE MESOLITHIC CEMETERY OF GROß FREDENWALDE (NORTH-EASTERN GERMANY) AND ITS CULTURAL AFFILIATIONS.......65 GROS FREDENVALDE (ŠIAURĖS RYTŲ VOKIETIJA) MEZOLITO LAIKOTARPIO KAPINYNAS IR JO KULTÜRINĖS SĄSAJOS .83

AKMENINIAI GLUDINTI KIRVIAI LIETUVOJE. TIPOLOGIJOS IR TERMINOLOGIJOS PROBLEMOS .85 GROUND STONE AXES IN LITHUANIA. PROBLEMS OF TYPOLOGY AND TERMINOLOGY 108

NEOLITHIC SOCIETIES AND THEIR POTTERY IN SOUTH-EASTERN LITHUANIA 111 NEOLITO BENDRUOMENĖS IR JỤ KERAMIKA PIETRYČIỤ LIETUVOJE. 142

OSSEOUS POINTS AND HARPOON HEADS FROM ŠVENTOJI SUBNEOLITHIC SITES, COASTAL LITHUANIA. FIRST TRACEOLOGICAL INSIGHT INTO THE WAY THEY WERE PRODUCED AND USED 147

KAULINIAI ANTGALIAI IR ŽEBERKLAI LIETUVOS PAJÜRIO ŠVENTOSIOS SUBNEOLITINĖSE GYVENVIETĖSE: GAMYBA IR NAUDOJIMAS PIRMU巳JŲ TRASOLOGINIŲ TYRIMỤ DUOMENIMIS 168 
Sławomir Kadrow

Frédéric Surmely

Rokas Vengalis, Jonas Volungevičius, Gintautas Vèlius, Albinas Kuncevičius, Justina Poškienè, Regina Prapiestienè

Andra Simniškytè

Inga Merkyte்

Rokas Vengalis
MACRO AND MICRO SCALE NEOLITHISATION PROCESSES IN SOUTH-EASTERN POLAND AGAINST THE BACKGROUND OF CENTRAL-EASTERN EUROPE 171

PIETRYČIŲ LENKIJOS NEOLITIZACIJOS PROCESAI MIKRO- IR MAKROLYGMENIMIS VIDURIO IR RYTŲ EUROPOS KONTEKSTE 187

CHARACTERIZATION OF TERTIARY FLINTS BY GEOCHEMISTRY: APPLICATION TO THE FRENCH TERRITORY.

TERCIARO TITNAGO PRANCÜZIJOS TERITORIJOJE CHARAKTERIZAVIMAS NAUDOJANT GEOCHEMINI METODĄ

ŽMOGUS PRIEŠ GAMTĄ: RELJEFO TRANSFORMAVIMAS İRENGIANT XIII-XIV A. KERNAVÉS PILI IR JO SUKELTI EROZINIAI PROCESAI ....... 207 MAN AGAINST NATURE: THE TRANSFORMATION OF THE RELIEF DURING THE CONSTRUCTION OF KERNAVĖ CASTLE IN THE $13^{\mathrm{TH}}-14^{\mathrm{TH}}$ CENTURIES AND THE EROSIONAL PROCESSES IT CREATED 248

KUPIŠKIO (AUKŠTUPĖNŲ) PILIAKALNIS: TEORINĖS PRIELAIDOS

IR TYRIMŲ REZULTATAI .255

HILLFORT OF KUPIŠKIS (AUKŠTUPĖNAI): THEORETICAL ASSUMPTIONS AND INVESTIGATION RESULTS 284

\section{KITAIP APIE ARCHEOLOGIJA /} ALTERNATIVE PERCEPTIONS OF ARCHAEOLOGY

Šarūnas Radvilavičius

KELIAUTOJO LAIKU UŽRAŠAI. 289

THE NOTEBOOK OF TIME TRAVELLER

\section{DISKUSIJOS / DISCUSSIONS}

STUDIES OF ANCIENT DNA. THE RACE FOR THE ULTIMATE ANSWER .293

SENOVĖS DNR TYRIMAI: KARŠTLIGIŠKOS ATSAKYMŲ PAIEŠKOS

\section{RECENZIJOS / REVIEWS}

ALGIMANTAS MERKEVIČIUS (SUD.), 2018. ANKSTYVOJO METALŲ LAIKOTARPIO GYVENVIETÉS LIETUVOJE (SETTLEMENTS OF EARLY METAL PERIOD IN LITHUANIA). 305

INFORMACIJA APIE PROJEKTUS / INFORMATION ABOUT THE PROJECTS 309

AUTORIŲ DĖMESIUI. 327 GUIDELINES FOR AUTHORS 


\title{
OSSEOUS POINTS AND HARPOON HEADS FROM ŠVENTOJI SUBNEOLITHIC SITES, COASTAL LITHUANIA. FIRST TRACEOLOGICAL INSIGHT INTO THE WAY THEY WERE PRODUCED AND USED
}

\author{
GRZEGORZ OSIPOWICZ1, JUSTYNA ORŁOWSKA², GYTIS PILIČIAUSKAS², \\ GIEDRE் PILIČIAUSKIENË ${ }^{4}$, MARIUSZ BOSIAK ${ }^{5}$
}

\begin{abstract}
${ }^{1}$ Institute of Archaeology, Nicolaus Copernicus University, Szosa Bydgoska 44/48 street, 87-100, Toruń, Poland, e-mail: Grzegorz.Osipowicz@umk.pl

${ }^{2}$ Institute of Archaeology, Nicolaus Copernicus University, Szosa Bydgoska 44/48 street, 87-100, Toruń, Poland, e-mail: justyna.orlowska@umk.pl

${ }^{3}$ Archaeology Department, Lithuanian Institute of History, Kražių g. 5, 01108, Vilnius, Lithuania, e-mail: gytis.piliciauskas@gmail.com

${ }^{4}$ Vilnius University, Department of Archaeology, Universiteto g. 7, 01513, Vilnius, Lithuania, e-mail: giedrepils@gmail.com ${ }^{5}$ Faculty of Chemistry, Nicolaus Copernicus University, ul. Gagarina 7, 87-100, Toruń, Poland, e-mail: bosiu@chem.umk.pl
\end{abstract}

This article presents the results of traceological analyses of bone points and harpoon heads discovered at hunter-gatherer-fisher sites 1, 3, 4, 6 and 23 in Šventoji, coastal Lithuania, c. 3500-2700 cal BC. The data obtained through the studies were used to interpret technological processes and operational chains resulting from the production of these artefacts, as well as in answering questions surrounding the function of some specimens. Another important result of the presented research is the confirmation, thanks to an SEM-EDX analysis, of the presence of an inlay in the decoration visible on one of the harpoon heads.

Keywords: Šventoji, Subneolithic-Neolithic, points, harpoon heads, bone, traceological analysis, SEM-EDX

Šiame straipsnyje yra pateikiami kauliniu strèlių antgaliu ir žeberklų, rastų Šventosios 1, 3, 4, 6 ir 23 akmens amžiaus gyvenvietese (3500-2700 cal BC), pirmujų trasologinių tyrimų rezultatai. Gauti duomenys leido rekonstruoti šiu dirbiniu gamybos procesa, atkurti technologiniu operaciju seka ir pasiūlyti galima kai kuriu dirbiniu paskirtị. Šiame darbe taip pat pateikiami ir vieno iš žeberklu rèžtame ornamente rasto užpildo SEM-EDX tyrimu rezultatai.

Reikšminiai žodžiai: Šventoji, subneolitas - neolitas, antgaliai, žeberklai, kaulas, trasologiniai tyrimai, SEM-EDX.

\section{INTRODUCTION}

Hunting weapon elements in the form of points and harpoon heads made of osseous raw materials constituted a significant piece of equipment for Stone Age hunters. Studies of these objects have a long history and are an important part of research on prehistoric communities. Items of this type are analysed in respect to typology (i.a. Clark 1936; Gramsch 2003; Galiński 2013), technology (i.a. David 2005; Zhilin 2017a; Orłowska, Osipowicz 2018), and function (i.a. Arndt, Newcomer 1986; Pokines 1998; Pétillon et al. 2016), whereas the knowledge obtained through these, aside from creating classic chronological-cultural classifications (e.g. Kozłowski 1969; Galiński 2013), are used in, among 


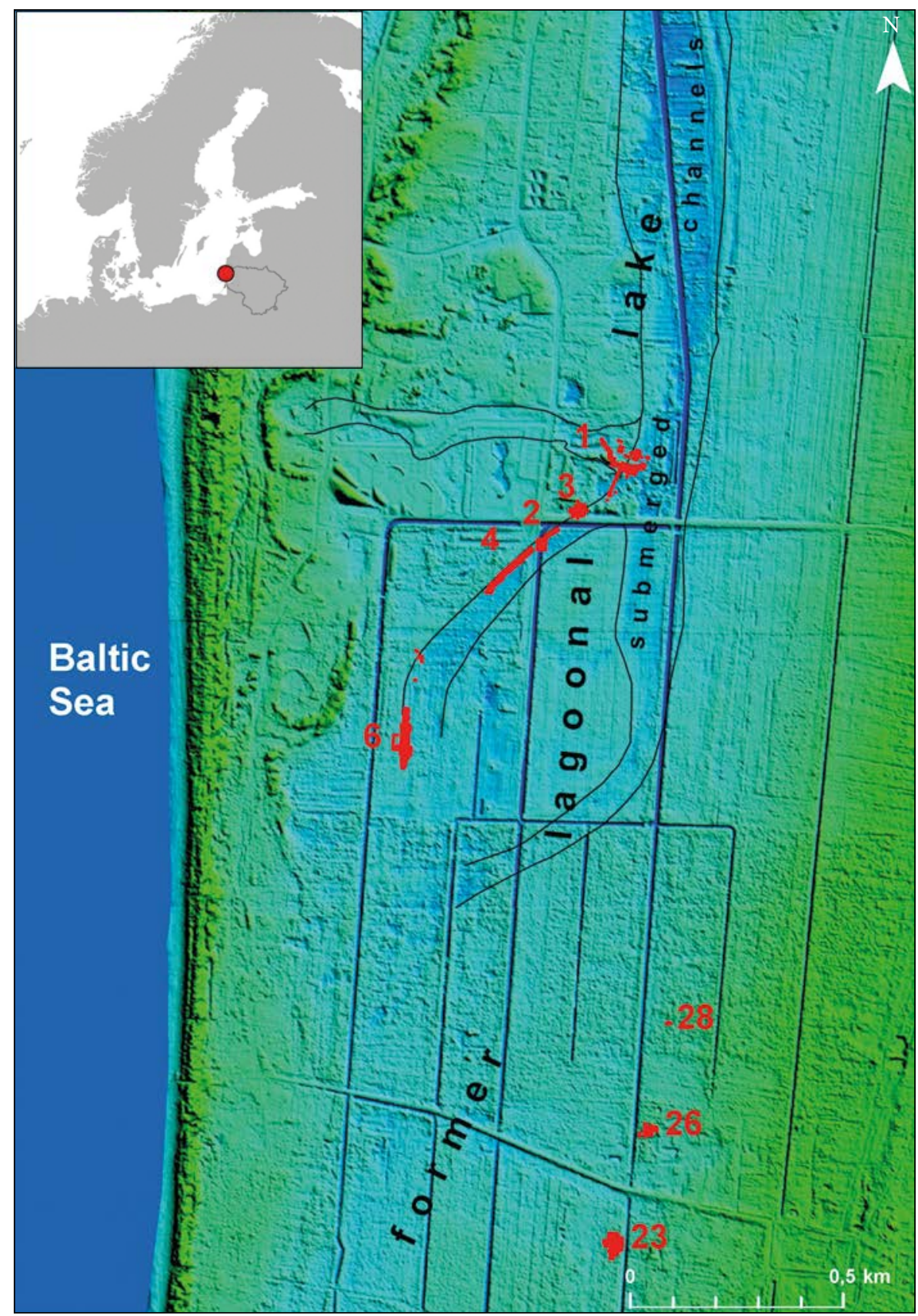

Fig. 1. Location of the sites in Šventoji. Drawing by G. Piličiauskas.

others, research on prehistoric hunting techniques (e.g. Cattelain 1997), the function of camps and settlements (Cattelain 2005; Piličiauskas et al. 2020), processing and ornamenting techniques used with objects made of osseous raw materials (e.g. Zhilin 1998; David 2005; Langley et al. 2016; Osipowicz et al. 2020), and the symbolic sphere of Stone Age peoples (e.g. Langley 2015; Osipowicz et al. 2019). At the same time, technological and functional studies are conducted on this type of artefact using more and more cutting-edge and highly diverse scientific instruments, in addition to the already 
classic stereoscopic and metallographic microscopes, scanning microscopy (SEM; Arndt, Newcomer 1986), and Micro-CT and macro-fracture methods (Bradfield, Lombard 2011), etc. Hence, studies on osseous projectile elements undoubtedly constitute an important element of modern archaeological research, particularly in addressing the issues of the oldest stages of the development of humanity.

A collection of these kinds of objects have also been obtained from the Subneolithic (aka Ceramic Mesolithic) and Neolithic levels of a complex of archaeological sites in Šventoji, which is located on Lithuania's northwest coast. This complex (Fig. 1) was discovered in 1966 by Mikelis Balčius and Rimute Rimantiene during irrigation work conducted in the region. At the time, dozens of archaeological sites and loose finds were identified, dated now (along with sites discovered later) to the period between $6000-500 \mathrm{cal}$ вс. They are located on a swampy Littorina sea terrace, $16 \mathrm{~km}$ long and up to $2.5 \mathrm{~km}$ wide, stretching between the city of Palanga and the Lithuanian-Latvian state border (Piličiauskas et al. 2012; Piličiauskas 2016). The sites were interpreted as habitation sites, refuse layers, fishing stations, and possibly pile dwelling settlements. A number are wetland sites with well-preserved organic material that was found in the gyttja of waterlogged lake deposits (Rimantienè 2005; Piličiauskas 2016; Luik, Piličiauskienè 2016). Human occupation at different sites was ${ }^{14} \mathrm{C}$ dated to $6000 \mathrm{cal} \mathrm{BC} \mathrm{(Šventoji} \mathrm{40),} \mathrm{4000-}$ 3700 cal BC (Šventoji 43 and 45), 3500-2500 cal BC (Šventoji 1-4, 6, 23, 41A, 42, 51, 52), and 2000700 cal BC (Šventoji 9, 41B, 47, 48) (Piličiauskas et al. 2012; Piličiauskas, Heron 2015; Piličiauskas 2016).

This article presents the results of traceological studies on a collection of bone points and harpoon heads obtained in the course of excavations at the Šventoji 1, 3, 4, 6 and 23 sites. The key objective of the presented studies was to attempt to interpret the technological processes and chains of operation accompanying the manufacture of the described artefacts, as well as to attempt to answer the question about how they were used.

\section{MATERIALS}

At the Šventoji 1, 3, 4, 6 and 23 sites, several dozen products made of osseous raw materials were found and can be classified as projectile point elements. This article presents the results of the microscopic study of 17 items, all artefacts that were available to the authors. They are stored at the National Museum of Lithuania in Vilnius under the inventory numbers provided in Table 1, which also includes other basic information regarding the analysed artefacts. All the items have been dated to the period between 3500 and $2700 \mathrm{cal} \mathrm{BC}$, i.e. to the Subneolithic (cf. Luik, Piličiauskienè 2016). Only a single harpoon from Šventoji 6 has been directly radiocarbon dated to 3627-3363 cal вС. The other studied artefacts were dated using context dates and stratigraphy. At Šventoji 1 and 2, the studied artefacts were found at the lower horizon together with Subneolithic pottery. At Šventoji 3 and 23 only Subneolithic pottery was present and it may, therefore, be assumed that all the bone tools are from the same period. Šventoji 6 contains both Subneolithic and Neolithic materials mixed in the same layer but stylistically, the studied bone tools should belong to the Subneolithic rather than Neolithic.

Šventoji 1 contributed two points which were made from elk (Alces alces L.) long bones, have flatconvex cross-sections, and have a shape resembling that of the so-called long needle-shaped arrowheads, known from, among others, Sakhtysh 9, Upper Volga Region, Russia (Zhilin 2015, p. 40, Fig. 2:1, 2).

Four of the analysed artefacts (two points and two harpoon heads) were found at Šventoji 3. The points were made from long bone fragments from a large ungulate and are irregular osseous plates with sharpened tips (Figs. 2C, 2D). Points of this type are often encountered at many Mesolithic sites, such as 


\begin{tabular}{|l|l|l|l|l|l|l|l|}
\hline No. & \multicolumn{1}{|c|}{ Site } & Inventory number & Type of artefact & Raw material & \multicolumn{1}{|c|}{ Species element } & \multicolumn{1}{c|}{ AMS dating } & \multicolumn{1}{c|}{ Figure } \\
\hline 1 & Šventoji 1 & EM2070:217 & Point & Metatarsus & Elk (Alces alces) & - & Fig. 2B \\
\hline 2 & Šventoji 1 & EM2070:219 & Point & Metapodia & Elk (Alces alces) & - & Fig. 2A \\
\hline 3 & Šventoji 3 & EM2132:20 & Point & Long bone & Large ungulate & - & Fig. 2D \\
\hline 4 & Šventoji 3 & EM2132:24 & Point & Long bone & Large ungulate & - & Fig. 2C \\
\hline 5 & Šventoji 3 & EM2132:30 & Harpoon-head & Metacarpus & Elk (Alces alces) & - & Fig. 2E \\
\hline 6 & Šventoji 3 & EM2132:34 & Harpoon-head & Long bone & Mammal & - & Fig. 2F \\
\hline 7 & Šventoji 4 & EM2136:173 & Point & Metapodial & Elk (Alces alces) & - & Fig. 3A \\
\hline 8 & Šventoji 4 & EM2136:172 & Harpoon-head & Long bone & Large ungulate & - & Fig. 3C \\
\hline 9 & Šventoji 4 & EM2136:194 & Harpoon-head & Long bone & Large ungulate & - & Fig. 3B \\
\hline 10 & Šventoji 6 & EM2138:651 & Point & Metacarpus & Elk (Alces alces) & - & Fig. 3E \\
\hline 11 & Šventoji 6 & EM2138:677 & Point & Tibia & Elk (Alces alces) & - & Fig. 3D \\
\hline 12 & Šventoji 6 & EM2138:666 & Harpoon-head & Long bone & $\begin{array}{l}\text { Auroch/cattle } \\
\text { (Bos primigenius/ } \\
\text { Bos taurus) }\end{array}$ & $\begin{array}{l}4670 \pm 40 \\
\text { BP (FTMC- } \\
\text { EF17) }\end{array}$ & Fig. 3F \\
\hline 13 & Šventoji 6 & EM2138:689 & Half-product & Metacarpus & Elk (Alces alces) & - & Fig. 3H \\
\hline 14 & Šventoji 6 & EM2138:694 & Harpoon-head & Long bone & Large ungulate & - & Fig. 3G \\
\hline 15 & Šventoji 23 & EM2110:42 & Point & Long bone & Mammal & - & Fig. 3J \\
\hline 16 & Šventoji 23 & EM2110:49 & Point & Long bone & Large ungulate & - & Fig. 3I \\
\hline 17 & Šventoji 23 & EM2110:84 & Harpoon-head & Long bone & Large ungulate & - & Fig. 3K \\
\hline
\end{tabular}

Table 1. Contextual information and a general description of the analysed artefacts.

at Ageröd I:A-H-C in Sweden (David 2005, p. 565, PL. 91), Hohen Viecheln in Germany (David 2005, pp. 516-517, PL. 42, PL. 43) or Ulkestrup Lyng Øst II (David 2005, p. 497, PL. 23) and Mullerup 1 (David 2005, p. 476, PL. 2) in Denmark.

The harpoon heads found at the site were fragmentarily preserved. The first is the middle part of a massive single-row harpoon made from an elk long bone (Fig. 2E). The second is most likely the tip together with one barb which was made from the long bone of an unidentified mammal (Fig. 2F).

One of the analysed points and two of the harpoon heads come from Šventoji 4. The fragmentarily preserved point (the tip) was made from an elk long bone (Fig. 3A) and presumably has a shape similar to those found at Šventoji 1. The first head is a nearly complete single-row harpoon made from the long bone of a large ungulate (Fig. 3B). The second is most likely also a single-row harpoon, but only its tip has been preserved (Fig. 3C). It displays traces of having been in a fire and was made from the long bone of a large ungulate. This tool may be related to the Gniewinotype harpoons, according to T. Galiński (Galiński 2013), and type no. 5 according to J. G. D. Clark's classification (Clark 1936). Similar specimens are known from, among others, late Mesolithic layers from the Zamostje II site in Russia (Lozovskaya, Lozovski 2013).

Five of the analysed artefacts were found at Šventoji 6. These include two points, a single-row harpoon head, a double-row specimen, and a semiproduct. Both points were made using the long bones of an elk. One has been entirely preserved and its form resembles the specimens from Šventoji 1 (Fig. 3D). As for the other, only its tip has been preserved (Fig. 3E); it is, most likely, an example of those tools sometimes referred to in literature as the bone heads of massive thrusting spears (Zhilin 2017b). Similar specimens are known, among others, 
A

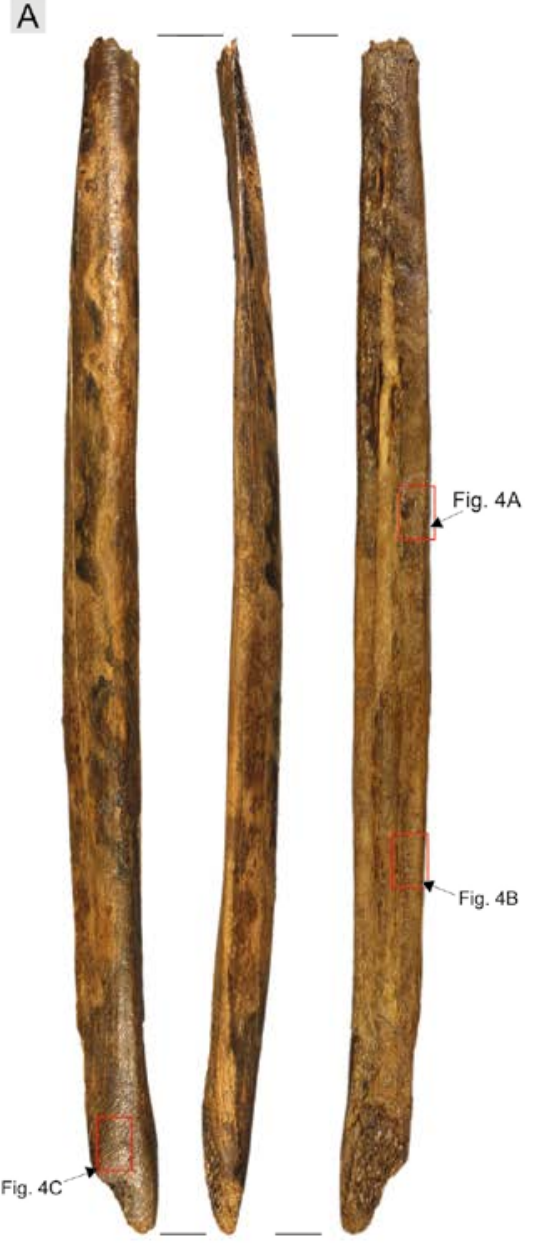

B
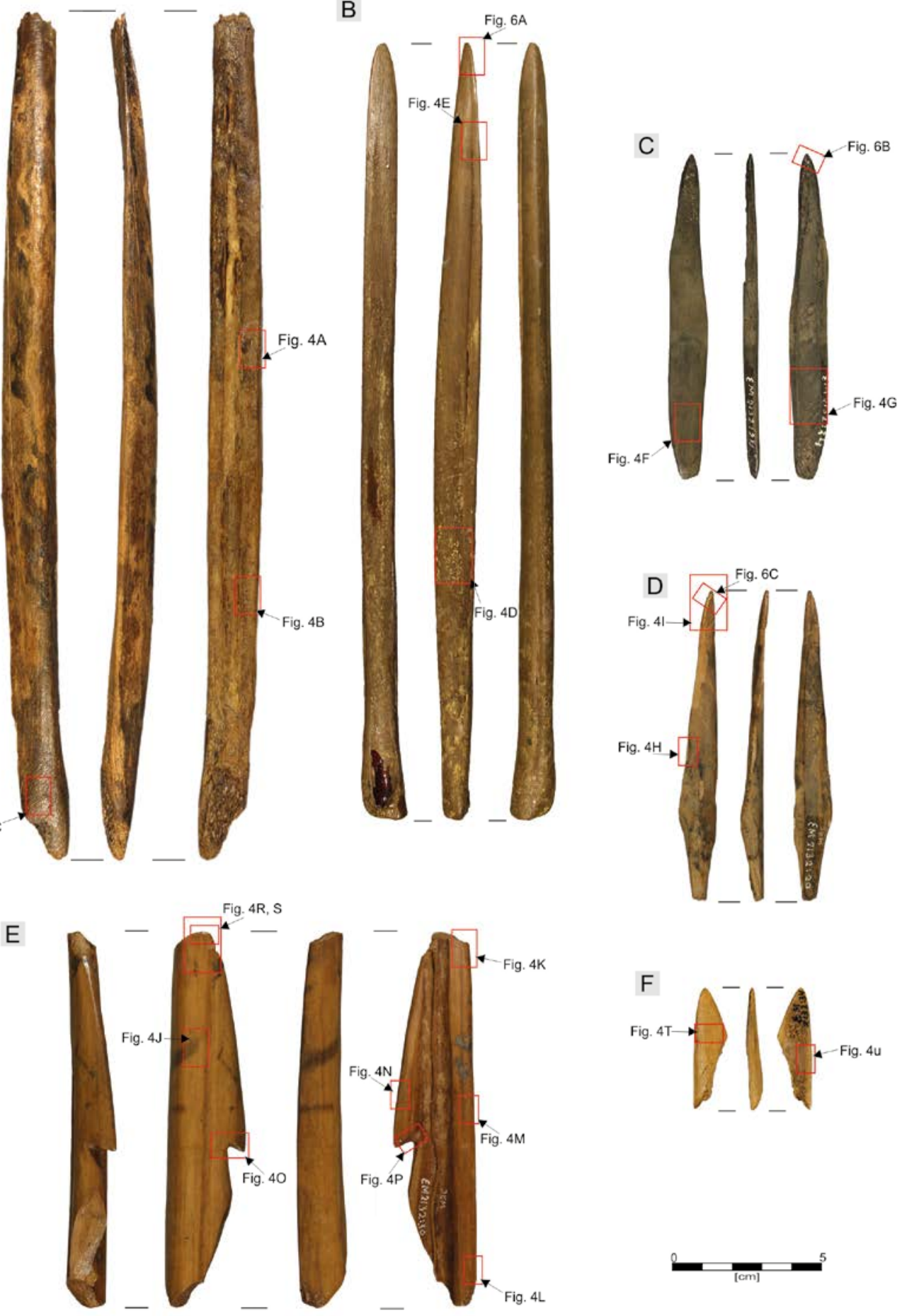
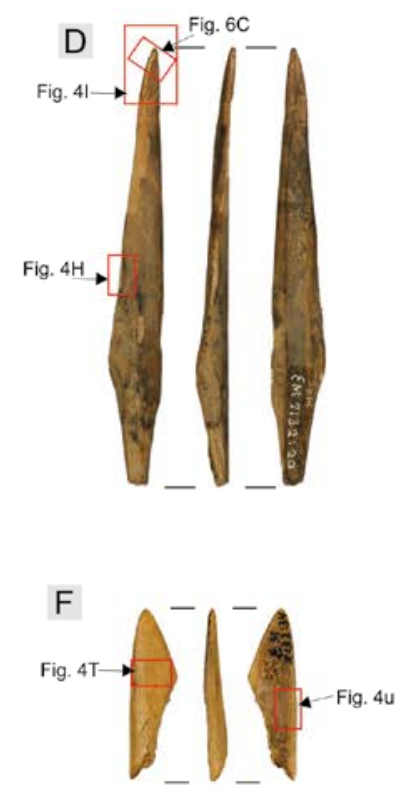

Fig. 2. The analysed points and harpoon heads from sites 1 and 3 in Šventoji. Photo by J. Orłowska. 


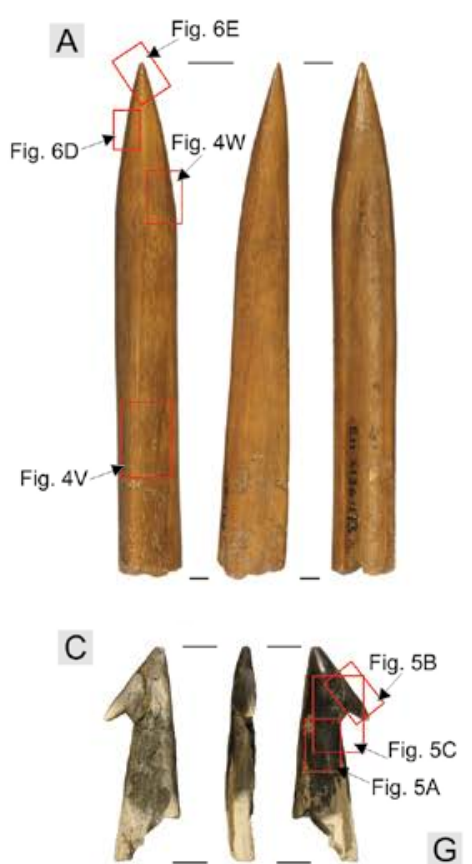

D
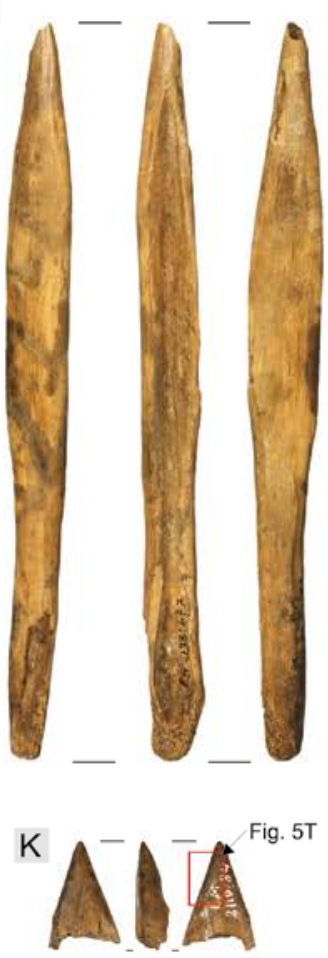

G
B

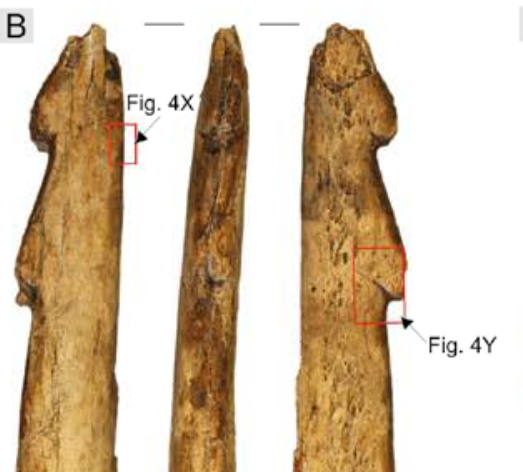

E
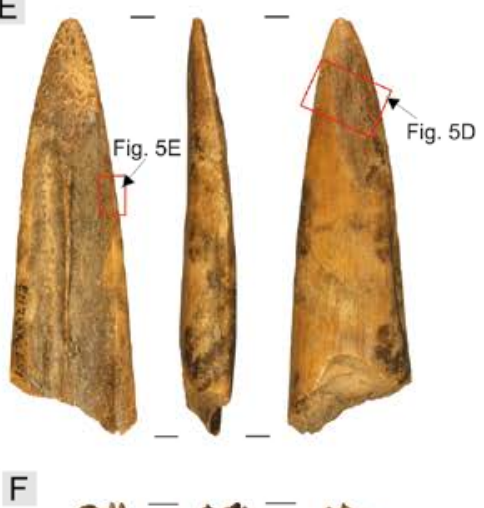
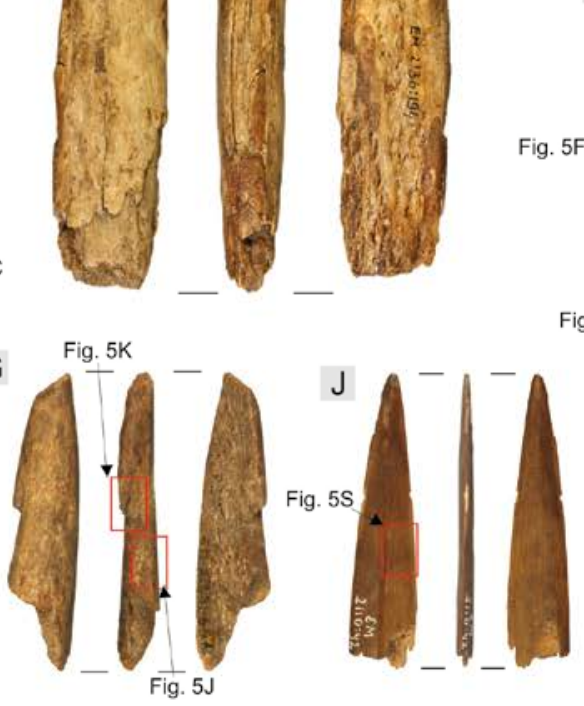

Fig. 5 ।
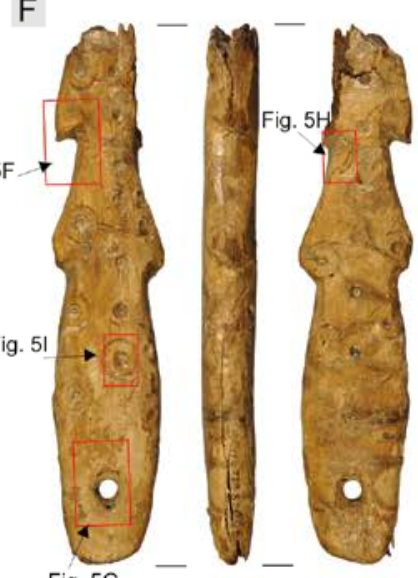

Fig. $5 \mathrm{G}$
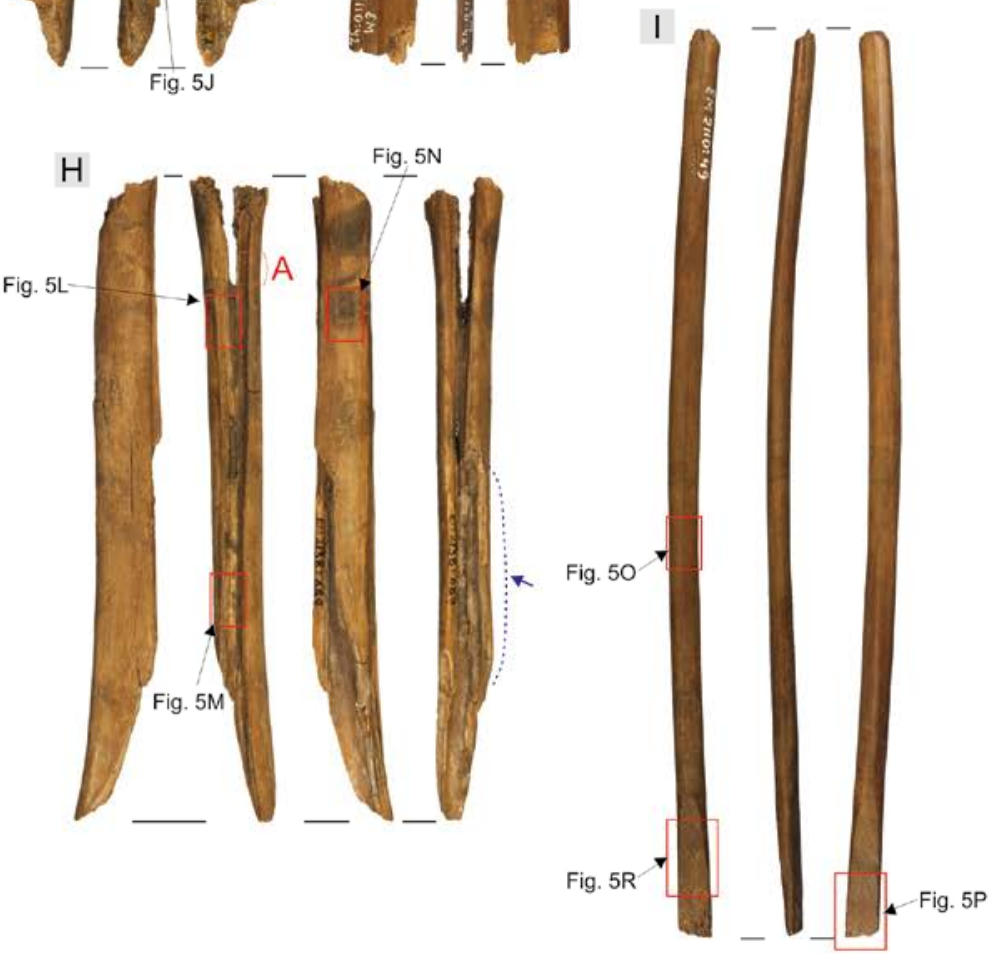

Fig. 3. The analysed points and harpoon heads from sites 4, 6, and 23 in Šventoji. Photo by J. Orłowska. 
from such (Mesolithic) sites as Ivanovskoye 3 and 7, Chernetskoye 8, and Stanovoye 1, 4 in Central Russia (Zhilin 1993; 2001; 2015), Zveinieki 2 (Zagorska 1980; 1993; Zagorska, Zagorskis 1989) and the lower find levels at Zvidze and Osa (Loze 1988) in Latvia, and Kunda Lammasmagi (Indreko 1948) in Estonia.

According to the ZooMs data, the double-row harpoon head from the site had been made from an aurochs (Bos primigenius B.) or cattle (Bos taurus L.) long bone (Fig. 3F). Its surface is decorated with a series of circles ( 5 on one side and 7 on the other side), lines that link some of them, and independent holes that have no analogies among artefacts with a similar chronology in Europe. The object, the only one from the entire collection, was AMS dated to $4670 \pm 40 \mathrm{BP}$ (FTMC-EF17), 3627-3363 cal вс (cf. Osipowicz et al. 2020). Some of the ornamentation visible on the specimen is filled with a black substance that might be a residue from some kind of incrustation. A sample of this substance was the subject of SEM-EDX studies, the results of which are presented below. The second harpoon head has been preserved only fragmentarily (the upper part with two barbs) and was made from the long bone of a large ungulate (Fig. 3G). The last object is a fragment of an elk long bone with traces of cutting running along the lateral edges, most likely a semi-product for manufacturing points (Fig. $3 \mathrm{H}$ ).

The study also includes three points from Šventoji 23. The first, which has been preserved without its tip, was made from the long bone of a large ungulate (Fig. 3I). It is a long, smooth artefact with a round cross-section and a double bevel base. Two points of this kind (Rimantienè 2005, pp. 439, 332, fig: 1,2) were found at the site, one of which was not available for analysis. Specimens of a similar type have come from, among others, the Olenij Ostrov site in Karelia (Gurina 1956, p. 71, fig. 36). The other two artefacts are only small blade fragments, the tips, one from the long bone of an unidentified mammal (Fig. 3J), the other the long bone of a large ungulate (Fig. 3K).

\section{METHODS}

A use-wear analysis of the artefacts was conducted using a Nikon SMZ-2T microscopic-computer kit fitted with a Nikon D7100 camera. This equipment allowed for objective magnification of the analysed specimens up to $12.6 \mathrm{x}$ (optically up to about 120x) as well as the computer digitalisation and processing of the optical images. This set was used to make all of the included microphotographs.

The SEM-EDX analysis was conducted using a scanning electron microscope from LEO Electron Microscopy Ltd., England, model no. 1430 VP from 2001. The device analyses the surface topography of solids and enables controlled vacuum conditions (1-270 Pa), which allows low-conductive and lowhydrated samples to be investigated without prior treatment (e.g., the application of a conductive coating). The device was connected to an energy dispersive X-ray spectrometer (EDX) Quantax 200 with an XFlash 4010 detector produced by Bruker AXS, Germany in 2008, owing to which it was possible to determine the elemental composition of various parts of the investigated objects.

The adopted terminology is based on a popular conceptual system (e.g. Newcomer 1974; d'Errico et al. 1984; Korobkova 1999; Legrand 2007; Christidou 2008; Osipowicz 2010; Buc 2011; Orłowska 2016), that was adjusted to the needs and requirements of the conducted analysis. Traces were recorded in accordance with their type, development, and location and distribution on the analysed tool. The morphological definitions of the points and harpoon heads were based on the Committee of Nomenclature of Prehistoric Bone Industry (Delporte, Mons 1988; Averbouh 1995). 


\section{RESULTS}

\section{Results of the technological analysis of the artefacts}

The state of the preservation of the analysed products varied. In many cases their surfaces were flaked, preventing microscopic observation. The study was also considerably hindered by the substance used for conserving the artefacts which had obscured the technological traces and prevented an analysis of the use-wear polish. A summary of the key data obtained in the course of the conducted study is shown in Table 2.

\section{Šventoji 1}

The points

Two large points were found at Šventoji 1, one of which has been preserved with its tip broken off (Fig. 2A), whereas in the other, in its entirety (Fig. 2B). The technological traces were better preserved on the former. The lateral (flat) lower side had been whittled, resulting in a corrugated surface and the poor preservation of the remains of incisions (Fig. 4A). In addition, the specimen had been ground at a specific angle to its axis. Traces of this treatment have been preserved in several areas (e.g. Fig. 4B), but they are most visible on the base (Fig. 4C).

The surface of the other point (Fig. 2B) has been relatively well preserved despite clear areas of flaking (mainly on the base - Fig. 4D). Basically, no traces related to the point's creation are visible on its surface, as they were removed as a result of grinding and also, most likely, during the previous polishing of the artefact. Traces of scraping/whittling using stone implements were only observed in some areas (Fig. 4E).

\section{Šventoji 3}

The points

The base of the first of the analysed points (Fig. 2C) was initially formed by scraping (Fig. 4F) and finished by grinding. Traces of this activity are visible primarily on the lower side of this part of the artefact (Fig. 4G). The tip of this specimen was probably formed in a similar manner.

The other tool (Fig. 2D) is better preserved (despite surface flaking here and there). Its upper surface bears no traces of processing, like a marrow cavity. Both surfaces of the fracture/splitting of the bone (the technique employed is unclear; presumably it was simply splintered) bear clear traces of scraping and grinding (Fig. $4 \mathrm{H}$ ). Both fractures that distinguish the point's shaft (Fig. 4I) were most likely made intentionally, although in this case the difference in the degree of patination between the natural upper surface and the bone fracture may raise questions as to whether it was formed using an older ecofact.

The harpoon heads

The results of the technological analysis of the first harpoon from the site (Fig. 2E) have already been published elsewhere (cf. Osipowicz et al. 2019). Here, it is only possible to note that the observed traces can be classified into two groups: (1) those related to preparing the original tool, i.e., the harpoon head, and (2) those formed as a result of altering it to serve other (secondary) function.

The first group consists of traces of scraping the object's entire surface, including the marrow cavity (Fig. 4J, K). In certain areas, chatter marks are clearly visible (Fig. 4L), indicating that the raw material was processed unsoftened. The surface with the barbs and the object's upper surface display traces of grinding (Fig. 4M), smoothing and polishing (Fig. 4N). The barb visible on the artefact was formed by sawing and scraping both of its sides (Fig. 4O, P).

The technological traces created through the transformation of the damaged (broken) harpoon into another type of tool primarily consist of traces of grinding (and the occasional whittling) performed to remove the bone's unevenness near the fracture and in the fracture area, as well as on the object's tip (Fig. 4R, S). 


\begin{tabular}{|c|c|c|c|c|c|c|c|c|c|}
\hline \multirow{2}{*}{ No. } & \multirow{2}{*}{ Site } & \multirow{2}{*}{$\begin{array}{l}\text { Inventory } \\
\text { and figure } \\
\text { number }\end{array}$} & \multirow{2}{*}{$\begin{array}{l}\text { Type of } \\
\text { artefact }\end{array}$} & \multicolumn{5}{|c|}{ Technological traces } & \multirow{2}{*}{$\begin{array}{c}\text { Functional } \\
\text { traces }\end{array}$} \\
\hline & & & & Tip & Shaft & Base & Barb & Other & \\
\hline 1 & $\begin{array}{c}\text { Šventoji } \\
1\end{array}$ & $\begin{array}{l}\text { EM2070:217; } \\
\quad \text { Fig. 2B }\end{array}$ & Point & $\begin{array}{l}\text { Scraping/ } \\
\text { whittling }\end{array}$ & $\begin{array}{c}\text { Probably } \\
\text { grinding and } \\
\text { polishing }\end{array}$ & - & - & - & $\begin{array}{l}\text { Rounding o } \\
\text { the tip, visi- } \\
\text { ble polish } \\
\end{array}$ \\
\hline 2 & $\begin{array}{c}\text { Šventoji } \\
1\end{array}$ & $\begin{array}{l}\text { EM2070:219; } \\
\quad \text { Fig. } 2 \mathrm{~A}\end{array}$ & Point & - & $\begin{array}{l}\text { Whittling, } \\
\text { grinding on } \\
\text { the ventral } \\
\text { side of the } \\
\text { bone }\end{array}$ & Grinding & - & - & - \\
\hline 3 & $\begin{array}{c}\text { Šventoji } \\
3\end{array}$ & $\begin{array}{l}\text { EM2132:20; } \\
\text { Fig. 2D }\end{array}$ & Point & - & $\begin{array}{l}\text { Scraping, } \\
\text { grinding }\end{array}$ & $\begin{array}{l}\text { Scraping, } \\
\text { grinding }\end{array}$ & - & - & $\begin{array}{c}\text { Peck-ness } \\
\text { and spin-off } \\
\text { breakages } \\
\text { on the tip, } \\
\text { associated } \\
\text { with roun- } \\
\text { ding and } \\
\text { polish }\end{array}$ \\
\hline 4 & $\begin{array}{c}\text { Šventoji } \\
3\end{array}$ & $\begin{array}{l}\text { EM2132:24; } \\
\text { Fig. 2C }\end{array}$ & Point & $\begin{array}{l}\text { Scraping, } \\
\text { grinding }\end{array}$ & - & $\begin{array}{l}\text { Scraping, } \\
\text { grinding } \\
\text { on the } \\
\text { ventral } \\
\text { side of } \\
\text { the bone }\end{array}$ & - & - & $\begin{array}{c}\text { Peck-ness } \\
\text { and spin-of } \\
\text { breakages } \\
\text { on the tip, } \\
\text { associated } \\
\text { with roun- } \\
\text { ding and } \\
\text { polish }\end{array}$ \\
\hline 5 & $\begin{array}{c}\text { Šventoji } \\
3\end{array}$ & $\begin{array}{l}\text { EM2132:30; } \\
\text { Fig. } 2 \mathrm{E}\end{array}$ & $\begin{array}{l}\text { Harpoon- } \\
\text { head }\end{array}$ & - & $\begin{array}{l}\text { Scraping, } \\
\text { grinding, } \\
\text { polishing }\end{array}$ & - & $\begin{array}{l}\text { Sawing } \\
\text { and scra- } \\
\text { ping from } \\
\text { two sides }\end{array}$ & \begin{tabular}{|c} 
Reutili- \\
zation by \\
grinding \\
and \\
whittling \\
the apex \\
part of \\
the tool
\end{tabular} & - \\
\hline 6 & $\begin{array}{c}\text { Šventoji } \\
3\end{array}$ & $\begin{array}{l}\text { EM2132:34; } \\
\text { Fig. } 2 \mathrm{~F}\end{array}$ & $\begin{array}{l}\text { Harpoon- } \\
\text { head }\end{array}$ & Scraping & $\begin{array}{l}\text { Scraping } \\
\text { (except the } \\
\text { marrow ca- } \\
\text { vity) }\end{array}$ & - & - & - & - \\
\hline 7 & $\begin{array}{c}\text { Šventoji } \\
4\end{array}$ & $\begin{array}{l}\text { EM2136:173; } \\
\text { Fig. 3A }\end{array}$ & Point & $\begin{array}{l}\text { Scraping, } \\
\text { whittling }\end{array}$ & $\begin{array}{l}\text { Scraping } \\
\text { (except the } \\
\text { marrow ca- } \\
\text { vity) }\end{array}$ & - & - & - & $\begin{array}{l}\text { Omnidi- } \\
\text { rectional } \\
\text { linear traces } \\
\text { below the } \\
\text { tip; polish o } \\
\text { the tip }\end{array}$ \\
\hline 8 & $\begin{array}{c}\text { Šventoji } \\
4\end{array}$ & $\begin{array}{l}\text { EM2136:172; } \\
\text { Fig. 3C }\end{array}$ & $\begin{array}{l}\text { Harpoon- } \\
\text { head }\end{array}$ & Whittling & $\begin{array}{c}\text { Scraping } \\
\text { (dorsal side } \\
\text { of the bone) }\end{array}$ & - & Whittling & - & - \\
\hline 9 & $\begin{array}{c}\text { Šventoji } \\
4\end{array}$ & $\begin{array}{l}\text { EM2136:194; } \\
\text { Fig. 3B }\end{array}$ & $\begin{array}{l}\text { Harpoon- } \\
\text { head }\end{array}$ & - & $\begin{array}{l}\text { Grinding } \\
\text { (ventral side } \\
\text { of the bone } \\
\text { and sides) }\end{array}$ & - & $\begin{array}{c}\text { Sawing } \\
\text { and } \\
\text { whittling } \\
\text { from two } \\
\text { sides }\end{array}$ & - & - \\
\hline 10 & $\begin{array}{c}\text { Šventoji } \\
6\end{array}$ & $\begin{array}{l}\text { EM2138:651; } \\
\text { Fig. 3E }\end{array}$ & Point & Scraping & $\begin{array}{l}\text { Scraping and } \\
\text { grinding on } \\
\text { the ventral } \\
\text { side of the } \\
\text { bone (except } \\
\text { the marrow } \\
\text { cavity) }\end{array}$ & - & - & - & - \\
\hline
\end{tabular}

Table 2. General results of the traceological analysis: traces observed on the analysed artefacts. 


\begin{tabular}{|c|c|c|c|c|c|c|c|c|c|}
\hline \multirow{2}{*}{ No. } & \multirow{2}{*}{ Site } & \multirow{2}{*}{$\begin{array}{l}\text { Inventory } \\
\text { and figure } \\
\text { number }\end{array}$} & \multirow{2}{*}{$\begin{array}{l}\text { Type of } \\
\text { artefact }\end{array}$} & \multicolumn{5}{|c|}{ Technological traces } & \multirow{2}{*}{$\begin{array}{c}\text { Functional } \\
\text { traces }\end{array}$} \\
\hline & & & & Tip & Shaft & Base & Barb & Other & \\
\hline 11 & $\begin{array}{c}\text { Šventoji } \\
6\end{array}$ & $\begin{array}{c}\text { EM2138:677; } \\
\text { Fig. 3D }\end{array}$ & Point & - & - & - & - & - & - \\
\hline 12 & $\begin{array}{c}\text { Šventoji } \\
6\end{array}$ & $\begin{array}{l}\text { EM2138:666; } \\
\text { Fig. 3F }\end{array}$ & $\begin{array}{l}\text { Harpoon- } \\
\text { head }\end{array}$ & - & Unreadable & $\begin{array}{l}\text { Drilling } \\
\text { from two } \\
\text { sides and } \\
\text { scraping } \\
\text { of the } \\
\text { prepared } \\
\text { hole }\end{array}$ & $\begin{array}{l}\text { Sawing } \\
\text { and } \\
\text { whittling } \\
\text { from two } \\
\text { sides }\end{array}$ & \begin{tabular}{|c} 
Deco- \\
ration \\
made by \\
drilling \\
circles, \\
most \\
likely \\
Using a \\
compass- \\
type \\
borer
\end{tabular} & - \\
\hline 13 & $\begin{array}{c}\text { Šventoji } \\
6\end{array}$ & $\begin{array}{c}\text { EM2138:689; } \\
\text { Fig. } 3 \mathrm{H}\end{array}$ & $\begin{array}{l}\text { Half-pro- } \\
\text { duct }\end{array}$ & & $\begin{array}{l}\text { Longitudinal } \\
\text { sawing on } \\
\text { the sides of } \\
\text { the bone; } \\
\text { scraping of } \\
\text { the dorsal } \\
\text { side of the } \\
\text { bone }\end{array}$ & & & $\begin{array}{l}\text { Traces of } \\
\text { splinter } \\
\text { tech- } \\
\text { nique } \\
\text { with a } \\
\text { wedge }\end{array}$ & \\
\hline 14 & $\begin{array}{c}\text { Šventoji } \\
6\end{array}$ & $\begin{array}{l}\text { EM2139:694; } \\
\text { Fig. 3G }\end{array}$ & $\begin{array}{l}\text { Harpoon- } \\
\text { head }\end{array}$ & - & Scraping & - & $\begin{array}{l}\text { Scraping } \\
\text { of the } \\
\text { surface of } \\
\text { the barbs; } \\
\text { chiseling/ } \\
\text { carving } \\
\text { to create a } \\
\text { barb }\end{array}$ & & \\
\hline 15 & $\begin{array}{c}\text { Šventoji } \\
23\end{array}$ & $\begin{array}{l}\text { EM 2110:42; } \\
\text { Fig. 3J }\end{array}$ & Point & Scraping & $\begin{array}{l}\text { Scraping } \\
\text { (except the } \\
\text { marrow ca- } \\
\text { vity) }\end{array}$ & & & & \\
\hline 16 & $\begin{array}{c}\text { Šventoji } \\
23\end{array}$ & $\begin{array}{l}\text { EM2110:49; } \\
\text { Fig. 3I }\end{array}$ & Point & - & $\begin{array}{c}\text { Scraping and } \\
\text { whittling, } \\
\text { additionally } \\
\text { probably } \\
\text { polishing }\end{array}$ & $\begin{array}{l}\text { Whittling } \\
\text { and } \\
\text { grinding } \\
\text { from two } \\
\text { sides }\end{array}$ & - & - & \\
\hline 17 & $\begin{array}{c}\text { Šventoji } \\
23\end{array}$ & $\begin{array}{c}\text { EM2110:84; } \\
\text { Fig. 3K }\end{array}$ & $\begin{array}{l}\text { Harpoon- } \\
\text { head }\end{array}$ & $\begin{array}{l}\text { Whittling, } \\
\text { scraping }\end{array}$ & - & & & & \\
\hline
\end{tabular}

Table 2. General results of the traceological analysis: traces observed on the analysed artefacts.

The other harpoon from the site has been preserved as only a small fragment (Fig. 2F). Its surface (except for the marrow cavity) bears traces of whittling using stone tools (Fig. 4T, U).

\section{Šventoji 4}

The point

The specimen was preserved fragmentarily (Fig. 3A). Traces of whittling using flint tools can be seen everywhere on the surface except the marrow cavity. The chatter marks are clearly observable in many areas (Fig. 4V). The tool's point was most likely repaired through additional whittling (as well as scraping) (Fig. 4W).

\section{The harpoon heads}

Despite being nearly complete, the state of the preservation of the first analysed artefact is poor due to considerable surface defects (Fig. 3B). The artefact's upper side bears virtually no traces of processing, the 

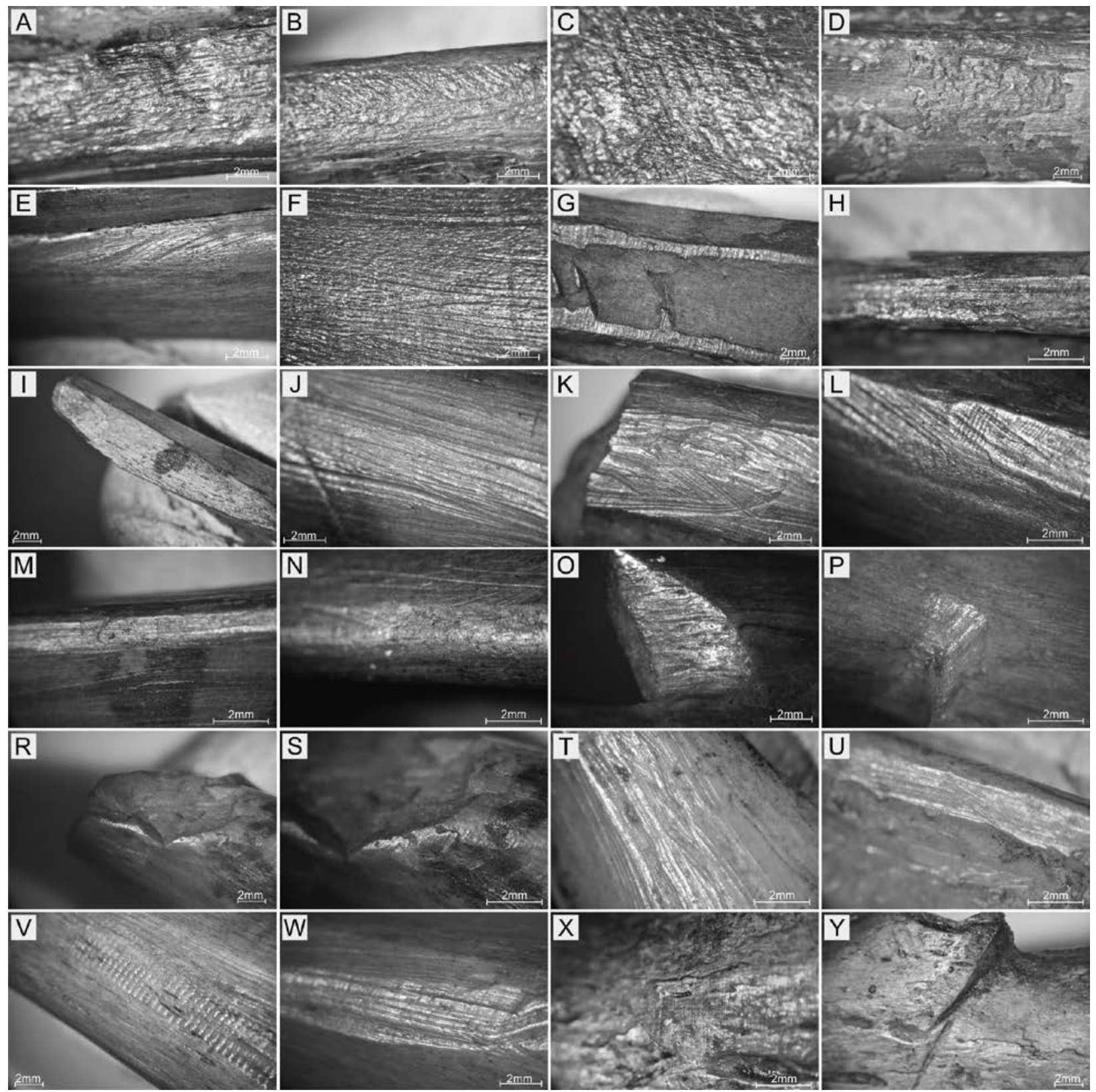

Fig. 4. Technological traces observed on the analysed artefacts from the sites in Šventoji. Photo by G. Osipowicz.

lower and lateral surfaces traces of grinding (Fig. 4X). The two preserved barbs were formed by cutting and whittling on both sides (Fig. 4Y).

The other harpoon from the site has been preserved fragmentarily and has been burnt (Fig. 3C). Its upper surface bears traces of whittling using stone tools (Fig. 5A), its lower side, no identifiable traces of this type, most likely due to the considerable damage. Its tip (Fig. 5B) and barb (Fig. 5C) have been formed by whittling. 


\section{Šventoji 6}

The points

The first of the analysed artefacts is relatively well preserved (Fig. 3D). Unfortunately, the attempt to identify the technological traces on its surface was unsuccessful due to the highly invasive characteristics of the substance used for conservation.

The other point found at the site is preserved fragmentarily (Fig. 3E). The traces of processing visible on its upper side are limited to traces of whittling using flint tools that can be seen only on the specimen's tip (Fig. 5D). Traces of this type were also recorded on its lower side, which was formed as a result of bone splitting and then ground (Fig. 5E). The marrow cavity bears no traces of processing.

\section{The harpoon heads}

Two artefacts of this type occurred at the site, one of which (the ornamented double-row harpoon head) (Fig. 3F), has already been described elsewhere (Osipowicz et al. 2020). The technological characteristic descriptions of this item have therefore been kept to an absolute minimum.

This specimen is poorly preserved with eroded surfaces and a broken tip. The traces of surface shaping are virtually unreadable. It can be only stated that the barbs displayed signs of whittling and sawing (Fig. 5F), the visible cross-drilled hole signs of whittling to expand the rim (Fig. 5G). The circles, which constitute the main element of the ornamental pattern visible on the harpoon, were made by drilling, most likely using double-barb tools such as a compass-type borer (cf. Tomenchuk, Storck 1997; Gaižauskas 2017), which was revolved around one (the longer) of the barbs. The characteristics of the technological traces observed inside these engravings indicate that they might have been formed using metal tools (cf. Osipowicz et al. 2020). Some of the circles were drilled twice (as they are double Fig. 5H). The holes visible inside have a V-shaped cross-section with clearly rounded walls (Fig. 5I).
The other artefact found at the site has been preserved only fragmentarily (Fig. 3G). Its upper surface, which is the natural surface of the bone, bears virtually no technological traces aside from traces of scraping visible in certain areas. This technique's most readable traces by far were observed on the barbs and the back of the harpoon opposite them (Fig. 5J). The only entirely preserved barb was distinguished by chiselling/carving (Fig. 5K).

\section{The semi-product}

Among the osseous products excavated at the site, an item with two slots on its lateral surfaces (Fig. $3 \mathrm{H}$ ) was also found. They were created by means of sawing (Fig. 5L), most likely supported by carving towards the bone head, as may be concluded given the unilateral manner in which the slots were deepened. Once spongy bone was reached at one of the bone heads, an attempt was made to split the bone using a wedge, which resulted in smoothing traces and an absence of spongy bone in zone A (the area where the wedge was driven through?) and the rough structure of the split (torn) spongy bone above in the area of the one head (cf. Fig. 3H). This process did not yield the expected result since slots continued to be cut, as might be concluded due to the presence of smoothing traces and the linear (longitudinal) orientation of the technological traces on the previously split surface (Fig. 5M). The item was abandoned before the process was completed, that is, before the bone was entirely split, as evidenced most likely by a large fracture visible on one of the slots (Fig. $3 \mathrm{H}-$ marked by a blue dotted line and an arrow; the result of a failed splitting?). One of the flat surfaces of the bone was additionally cleaned by whittling (Fig. 5N).

\section{Šventoji 23}

The points

The surface of the first of the analysed points (Fig. 3I) had been formed by scraping and whittling using flint tools (Fig. 5O), and then, very likely, by 

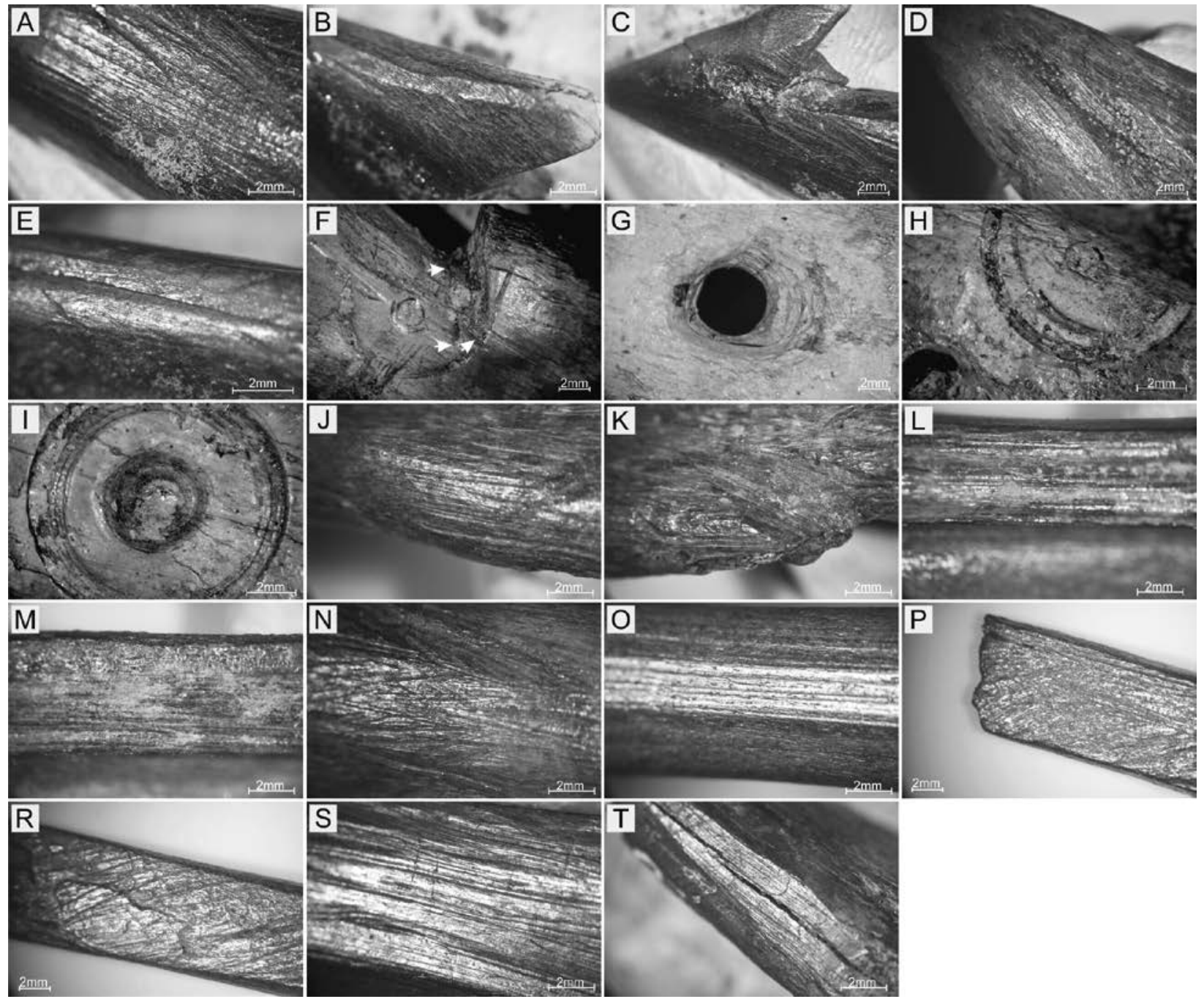

Fig. 5. Technological traces observed on the analysed artefacts from the sites in Šventoji. Photo by G. Osipowicz.

additional polishing. Its double bevel base was most likely formed by whittling, the traces of which are single (at present) linear streaks oriented parallel to the axis of the product (Fig. 5P). It was given its final shape through grinding (Fig. 5R).

The surface of the other analysed point (Fig. 3J) displays only traces of scraping with flint tools (Fig. 5S), all of which were illegible in the marrow cavity area.

\section{The harpoon head}

The only probable harpoon from the site was preserved as just a small fragment (Fig. 3K). Traces of whittling (Fig. 5T) and scraping using flint tools could be seen on the specimen.

\section{RESULTS OF THE ANALYSIS OF THE FUNCTION OF THE ARTEFACTS}

Despite the inability to use a metallographic microscope to analyse the artefacts considered in the article, some of them bore visible traces caused by their use.

The tip of one of the points from Šventoji 1 (Fig. 2B) is markedly rounded (Fig. 6A) and polished, 

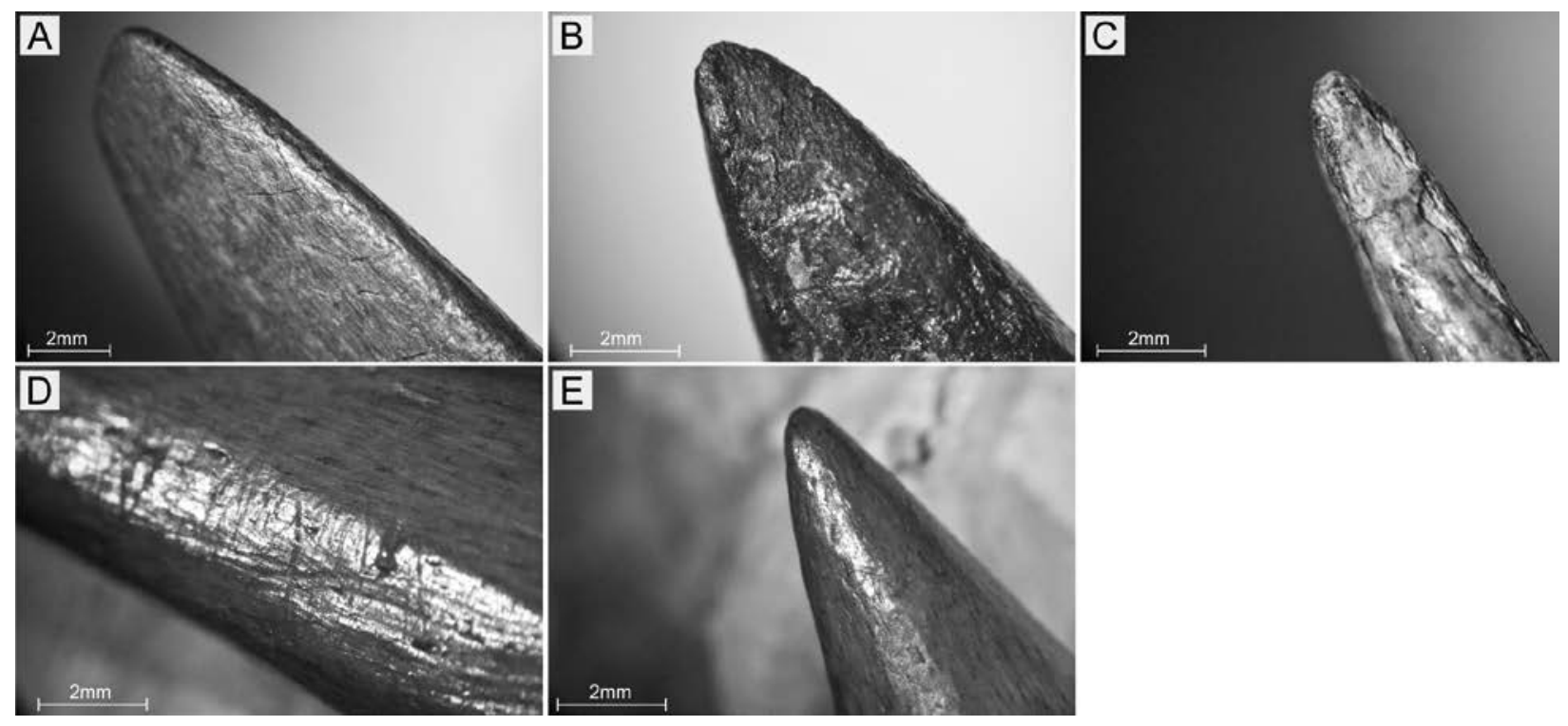

Fig. 6. Functional traces observed on the analysed artefacts from the sites in Šventoji. Photo by G. Osipowicz.

which possibly indicates contact with a soft material of organic origin. Two other points (Fig. 2C, D), which were found at Šventoji 3, display traces of impact characteristics in the form of delicate crush damage and spin-off fractures (Fig. 6B, C). On their tips, a rounding and a glossy polish are also visible, which are indicative of contact with a soft material. In turn, the edge of the tip of the tool of the discussed type from Šventoji 4 (Fig. 3A) bears clear omnidirectional linear traces (mainly short striations of various types - Fig. 6D), which indicate that the specimen was used for an activity of a rotational nature (drilling?) performed on an unspecified material (most likely relatively hard). However, the very tip of this tool bears no such traces (most likely they were destroyed through the creation of the usewear polish - Fig. 6E).

Clear use-wear traces were observed on only one harpoon head. This most likely stems from primarily the high level of damage inflicted on artefacts of this type. The specimen on which they occur is an item from Šventoji 3 (cf. Osipowicz et al. 2019) that was repurposed as a grinder.

\section{Results of the SEM-EDX analysis of the sample of the substance from a harpoon, inv. no. EM2138:666}

As a result of the analysis of the sample taken, it has been concluded (cf. Fig. 7; Table 3) that the high carbon levels and concurrent low calcium levels most likely point to an organic material. Only traces of silica $(0.09 \%$ and $0.25 \%)$, phosphorus $(1.15 \%$ and $1.44 \%)$, sulphur $(0.75 \%$ and $1.02 \%)$, calcium $(0.67 \%$ and $0.74 \%)$, and copper ( $0.32 \%$ each), along with a slightly higher amount of iron (2.73\% and $1.96 \%)$ were identified on the larger surfaces (zones 32957, 32960). The high amount of potassium in one area (zone 32958; Table 3) indicates the likely presence of plant ash that gives the substance a black colour. The increased levels of aluminium (6.04\%) and silica (12.96\%) in this area can be considered a probable indication of a clay binder that was used to keep the filling (incrustation) in the ornamentation, as is seen in the case of a chronologically similar T-shaped pendant from the Globular Amphora Culture at the Kowal 14 site in Poland (Rumiński, Osipowicz 2014). 


\begin{tabular}{|l|l|l|l|l|l|l|l|l|l|l|l|}
\hline \multicolumn{1}{|l|}{ Mass percent (\%) } \\
\hline \multicolumn{1}{|c|}{ Spectrum } & $\mathbf{C}$ & $\mathbf{O}$ & $\mathbf{M g}$ & $\mathbf{A l}$ & $\mathbf{S i}$ & $\mathbf{P}$ & $\mathbf{S}$ & $\mathbf{K}$ & $\mathbf{C a}$ & $\mathbf{F e}$ & $\mathbf{C u}$ \\
\hline $\mathbf{3 2 9 5 7}$ & 26.85 & 65.20 & - & 2.18 & 0.09 & 1.15 & 0.75 & 0.07 & 0.67 & 2.73 & 0.32 \\
\hline $\mathbf{3 2 9 5 8}$ & 15.45 & 54.34 & - & 6.04 & 12.96 & 1.02 & 0.32 & 7.68 & 0.39 & 1.41 & 0.38 \\
\hline $\mathbf{3 2 9 5 9}$ & 23.75 & 62.82 & 0.04 & 2.65 & 5.69 & 1.39 & 0.46 & 0.42 & 0.50 & 1.94 & 0.33 \\
\hline $\mathbf{3 2 9 6 0}$ & 27.06 & 64.70 & 0.35 & 2.09 & 0.25 & 1.44 & 1.02 & 0.09 & 0.74 & 1.96 & 0.32 \\
\hline Mean value: & 23.28 & 61.77 & 0.10 & 3.24 & 4.75 & 1.25 & 0.64 & 2.06 & 0.57 & 2.01 & 0.34 \\
\hline Sigma: & 5.43 & 5.06 & 0.17 & 1.88 & 6.07 & 0.20 & 0.31 & 3.75 & 0.16 & 0.55 & 0.03 \\
\hline Sigma mean: & 2.72 & 2.53 & 0.08 & 0.94 & 3.03 & 0.10 & 0.15 & 1.87 & 0.08 & 0.27 & 0.02 \\
\hline
\end{tabular}

Table 3. Results of the SEM-EDX analysis of the sample taken from the harpoon head, inv. no. EM2138:666.

Mass percent (\%).

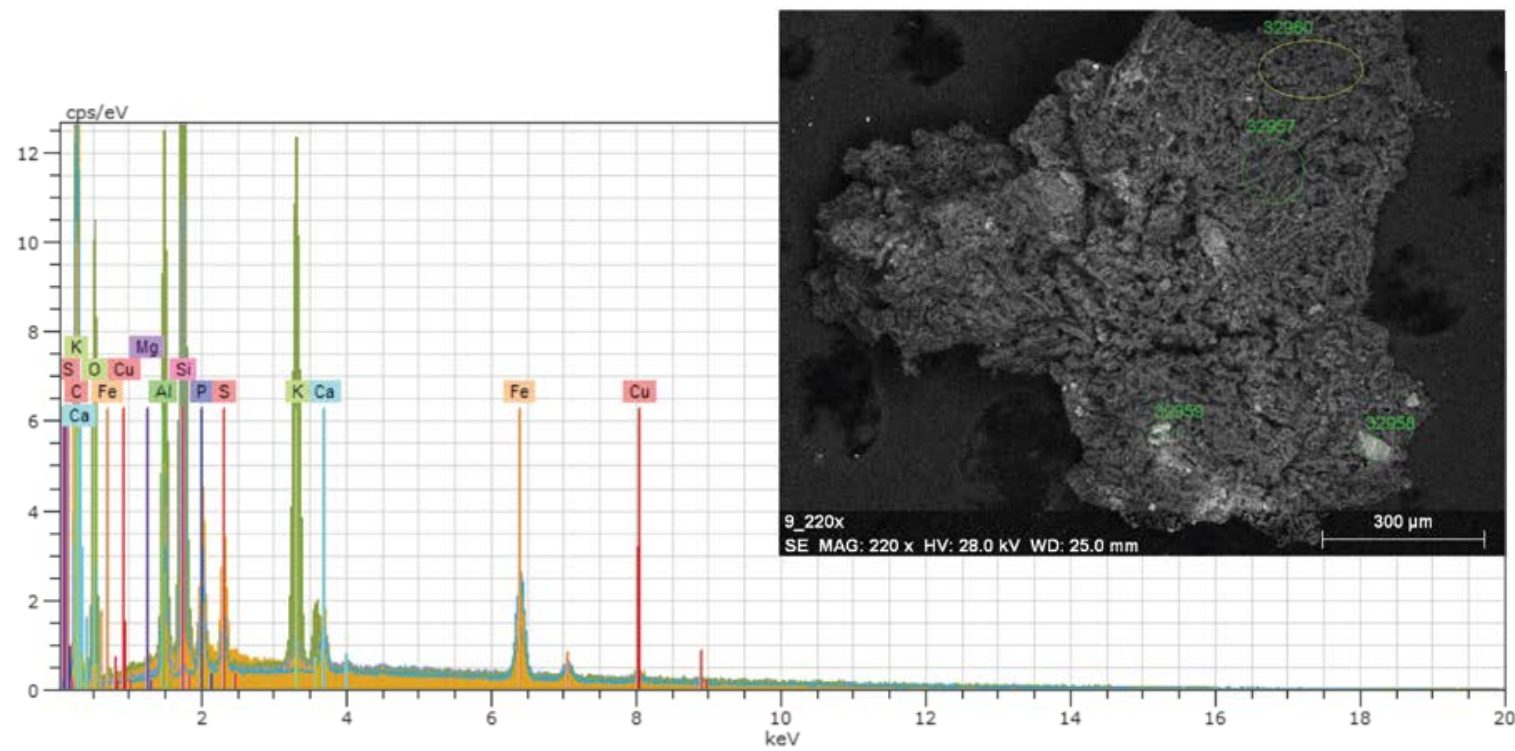
32957 Date:5/22/2018 11:27:02 AM
32958 Date:5/22/2018 11:28:37 AM
$\mathrm{HV}: 28.0 \mathrm{kV}$
Puls th.:6.83kcps
$\mathrm{HV}: 28.0 \mathrm{kV}$
Puls th.:12.46kcps
32959 Date:5/22/2018 11:29:23 AM
$\mathrm{HV}: 28.0 \mathrm{kV}$
Puls th.:9.05kcps
32960 Date:5/22/2018 11:30:30 AM
$\mathrm{HV}: 28.0 \mathrm{kV}$
Puls th.:9.55kcps

Fig. 7. Results of the SEM-EDX analysis of the sample taken from the harpoon head, inv. no. EM2138:666 (compare Table 3).

\section{DISCUSSION}

The results of the conducted traceological analyses allow one to reconstruct the chain of treatments performed during the manufacture of the osseous projectile point insets found at Šventoji, at least to some extent. Unfortunately, it is impossible to fully and reliably recreate the initial stages of this manufacturing process, i.e. the stage of obtaining matrices that were then transformed into points and harpoon heads of various types (e.g. David 2007). However, given the characteristics of the only semiproduct to depict this process (Fig. $3 \mathrm{H}$ ), it can be suggested that at that stage, at least in some cases, the so-called groove and splinter technique was employed (Clark, Thompson 1953). It is well known from the 
Mesolithic contexts of northern Europe (i.e. David 2007), while in Eastern Europe it occurred in other contexts at early-Holocene sites in the Upper Volga Region (Zhilin 1998). Nevertheless, the technological traces recorded on the small points from Šventoji 3 (Fig. 2C, D) indicate that in some cases semi-products were obtained by means of simple bone splitting with no additional preparatory treatment (cutting).

The points were given the required shape as a result of surface processing using three basic techniques, namely, scraping, whittling, and grinding (cf. Table 2). Processing of this kind was usually not applied to entire objects but only specific areas, i.e., the tip, the lower surface (mainly the surfaces of fractures formed as a result of splitting the raw material, excluding the marrow cavity) and, sporadically, the base. This approach and the applied techniques find analogies among other products of this type dated to the middle and younger stage of the Stone Age (Clark 1954; Zhilin 1998; David 2005).

Due to the high level of damage, a more precise technological analysis of the harpoon heads considered in the study was only possible in certain specific cases. The general rules for the final stage of shaping the surface do not seem to differ from those observed for the points. The basic technique applied in this process was scraping in the tip area, surfaces fractured on the lower side (excluding the marrow cavity), barbs, and (in the case of single-row specimens) the back part opposite them. The natural upper surfaces of the bone (aside from the tips of the harpoons) bear virtually no traces of processing. Sporadically, grinding was also applied for finishing purposes.

The barbs were usually created through bilateral sawing combined with scraping or whittling. In one case, the carving/chiselling technique (Fig. 3G; Fig. 5K) was used to this end.

The described way of making harpoon heads observed in the case of the Šventoji specimens has a wide range of analogies at the Early-Holocene hunter-gatherer sites in Europe, among others, at Kunda Lammasmägi in Estonia, Zamostje in Russia, and Zvejnieki 2 in Latvia (David 2005; Zhilin 2013). Analogies regarding the techniques used to make the barbs were also provided by finds from the Polish Lowland (Orłowska, Osipowicz 2018).

On the surface of one of the harpoons described in the article a complex ornament can be seen (Fig. 3F). As noted above, it was most likely made using metal tools (cf. Osipowicz et al. 2020). The results of the conducted chemical analyses show that it was possibly filled with an incrustation inlay prepared from plant ash and a clay substance.

It is very rare for traces of this kind of filling to be preserved on Stone-Age bone products (particularly those related to hunter-gatherer communities). Examples of these are, for instance, Mesolithic batons from Gro $\beta$ Rönnau and points from Wustermark, Germany, as well as hafts from Refsvindinge Mose, Denmark (Müller 1918; Schwantes 1939; Płonka 2017; 2019). The aim of incrusting was most likely to improve the readability of the created ornaments that would have been poorly visible on the bright freshly processed bone material. Even a small amount of charcoal or hearth ashes applied onto the ornaments rendered them more visible. This was most likely also applied to the Late Palaeolithic artefact from Rusinowo, Poland (Płonka, Kowalski 2017, p. 185).

It is commonly believed that bone points and harpoon heads served as hunting weapons and could be used for hunting a variety of animals. Mesolithic points have been found in the context of the remains of fish such as pike (Esox lucius L.) and land animals such as red deer (Cervus elaphus L.), elk, boar (Sus scrofa L.), and even dogs (Canis lupus familiaris L.) (Verhart 2000). Some harpoons have been found in contexts with the remains of seals (Verhart 2000), large fish, and beavers (Zhilin 2014). Therefore, the hunters inhabiting Šventoji could have used the items analysed in the article for such activities as seasonal seal hunting, elk hunting, or boar hunting, the bones 
of such animals (aside from fish remains) constituting the greater part of the bone inventory at the Šventoji 1-4 and 6 sites (Rimantienè 2005, Figs. 30, 123; Luik, Piličiauskienè 2016).

Unfortunately, the results of the traceological analyses do not allow for a broader statement regarding the rules governing the use of the bone products included in the article, which, due to their form, have been classified as projectiles. However, it may be suggested that in many cases such automatic functional interpretations may be unjustified, particularly in the case of the so-called points. Although some of the analysed specimens of this sort (Fig. 2C, D) display retouching along with impact traces (cf. Francis 2002; Bradfield, Lombard 2011; Buc 2011; Petillon et al. 2016), which could confirm that they were used as projectiles, these traces are very delicate and it cannot be ruled out that they were formed as a result of a different activity, e.g. sewing or piercing, the function of which was suggested by the shape of these artefacts (Rimantienè 2005, pp. 65-67, 98-99, figs. 32, 115). It should be noted here that the aforementioned specimens bear no well-developed polish that is characteristic of implements used in this manner (LeMoine 1991; Legrand 2007). However, this might be due to a short period of use.

Significant doubts regarding the function of a projectile point inset may also arise when examining traces observed on another artefact, specifically, the long needle-shaped specimen with a natural base (Fig. 2B) that bears no traces of impact damage but only that of polishing and rounding indicative of contact (piercing?) with a soft, most likely organic material. Lastly, this function unquestionably was not fulfilled by the morphologically similar broken point (Fig. 3A), on which clear linear traces were identified indicating that it was employed in a rotational activity, most likely drilling.

Therefore, the example of the site complex in Šventoji clearly shows that the problem of identifying the application of artefacts jointly classified as points and often automatically related to throwing weapons undoubtedly requires further and more in-depth functional research.

The points with barbs, also called harpoons, are just as commonly interpreted as hunting weapons related mainly with hunting in water environments. Sadly, none of the analysed specimens of this sort bears damage that could confirm this opinion, which most likely stems primarily from their intense postdepositional damage. However, one of the analysed harpoon heads bears use-wear traces that once again indicate that automatic assignment of function to the artefact made solely on the basis of shape is not always necessarily correct, that is, it does not always refer to the only way in which a given specimen was used, referring specifically here to the point of the reworked harpoon head repurposed as a grinder (Fig. 2E; cf. Osipowicz et al. 2019).

Due to the relatively small number of bone points and harpoon heads found at sites in Šventoji and their relatively high morphological diversity, they cannot be used for more specific interpretations of the function of individual camps. This is because at each of the considered sites various types of these artefacts occurred individually one next to another. Perhaps further research on the described collection conducted using a metallographic microscope and SEM will allow for a further-reaching functional interpretation.

\section{CONCLUSIONS}

The conducted studies constitute the first traceological analysis performed in such detail on bone points and harpoon heads found in the course of investigating the complex of prehistoric sites in Šventoji. To summarize, the obtained data should lead to the conclusion that attention be drawn to the high degree of uniformity of the technological treatments carried out in the course of manufacturing artefacts of different typology and at the same time, 
their exceptionally high minimalism, that is, the fact that only activities necessary for forming a given artefact were performed. For this reason, it can be stated that most of the analysed objects are most likely household tools and not cult-related items, the fabrication of which would most likely entail a greater attention to detail.

Most of the analysed artefacts most likely served the function of a projectiles point inset. However, one should consider the identification of objects for a different purpose. In this respect, the continuation of this research may constitute an important element of studies on the function of specific camps at Šventoji.

An important result of the presented studies is also the confirmation of the incrustation of the ornament visible on one of the analysed harpoons. This artefact is very likely an example of the repurposing of an imported item, used over a very long period (cf. Osipowicz et al. 2020). A subsequent investigation stage should aim to determine the moment when it was created. It should be determined whether this involves an act that happened at the time the ornament was made or after the item was repurposed and given the form of a harpoon. The solution to this dilemma could serve as a significant element of discussion on the familiarity with and application of this sort of treatment among the Subneolithic communities of present-day Lithuania.

\section{Acknowledgments}

We are very grateful to Shae Neko Jensen from Aarhus University in Denmark for correcting this article's language. We would also like to thank the employees of the National Museum of Lithuania, especially Saulius Žegunis, for allowing access to the materials and for creating a workplace and atmosphere that facilitated the conducting of the analyses. Finally, we are very thankful for the comments of the anonymous reviewers, which allowed this article to be refined.

\section{REFERENCES}

Arndt, S., Newcomer, M.H., 1986. Breakage patterns on prehistoric bone points. In: Roe, D. A., ed. Studies in the Upper Palaeolithic of Britain and Northwest Europe. Oxford: Archaeopress (BAR International Series, 296), 165-173.

Averbouh, A., 1995. Fiche typologique de l'industrie osseuse préhistorique 7. Eléments barbelés et apparentés. Treignes: CEDARC.

Bradfield, J., Lombard, M., 2011. A macrofracture study of bone points used in experimental hunting with reference to the South African Middle Stone Age. South African Archaeological Bulletin, $66,67-76$.

Buc, N., 2011. Experimental series and use-wear in bone tools. Journal of Archaeological Science, 38, 546-557.

Cattelain, P., 1997. Hunting during the Upper Paleolithic: Bow, spearthrower, or both? In: Knecht, H., ed. Projectile technology. New York: Plenum Press, 213-240.

Cattelain, P., 2005. Propulseurs magdaléniens: marqueurs culturels régionaux. In: Dujardin, V., ed. Industrie osseuse et parures du Solutréen au Magdalénien en Europe. Actes de la table ronde sur le Paléolithique supérieur récent, Angoulême (Charente), 28-30 mars 2003. Paris, 301-317.

Christidou, R., 2008. An application of microwear analysis to bone experimentally worked using bronze tools. Journal of Archaeological Science, 35, 733-751.

Clark, J. D. G., 1936. The Mesolithic settlement of northern Europe; a study of the food-gathering peoples of northern Europe during the early post-glacial period. Cambridge: Cambridge University Press.

Clark, J. G. D., 1954. Excavations at Star Carr: an early Mesolithic Site at Seamer near Scarborough, Yorkshire. Cambridge: Cambridge University Press.

Clark, J.G.D., Thompson, M. W., 1953. The groove and splinter technique of working antler in upper 
Paleolithic and Mesolithic Europe. Proceedings of the Prehistoric Society, 19 (2), 148-60.

David, É., 2005. Technologie osseuse des derniers chasseurs préhistoriques en Europe du Nord (XeVIIIe millénaires avant J.-C.). Le Maglemosien et les technocomplexes du Mésolithique. Monographie de thèse.

David, É., 2007. Technology on bone and antler industries: a relevant methodology for characterizing early post-glacial societies (9th-8th millennium $\mathrm{BC}$ ). In: Gates St.-Pierre, C., Walker, R., eds. Bones as Tools: current methods and interpretations in worked bone studies. Oxford: Archaeopress (BAR International Series, 1622), 35-50.

Delporte, H., Mons, L., 1988. Sagaies. Fiche générale. In: Delporte, H., Hahn, J., Mons, L., Pinçon, G., Sonneville-Bordes, D., eds. Fiches Typologiques de l'Industrie Osseuse Préhistorique: Cahier I, Sagaies. Aix-en-Provence: Publications de l'université de Provence, 1-9.

D’Errico, F., Giacobini, G., Peuch, P. F., 1984. Varnish replicas: a new method for the study of worked bone surfaces. Ossa. International Journal of Skeletal Research, 9-11, 29-51.

Francis, V., 2002. Twenty interesting points: an analysis of bone artefacts from Platypus Rockshelter. Queensland Archaeological Review, 13, 63-70.

Gaižauskas, L., 2017. Neolitinio žeberklo gamyba ir ornamentavimas apskritimų motyvu naudojant titnaginius įrankius. In: Luchtanienė D., ed. Eksperimentine Archeologija. Materialaus paveldo rekonstrukcija, II tomas. Vilnius: Akademinè leidyba, 81-94.

Galiński, T., 2013. Typological, chronological and cultural verification of Pleistocene and early Holocene bone and antler harpoons and point from the southern Baltic zone. Przeglad Archeologiczny, 61, 93-144.

Gramsch, B., 2003. Spindelförmige Knochenspitzen aus Brandenburg (BRD). Bulletin de la Société Préhistorique Luxembourgeoise, 25, 43-72.
Gurina, N. N., 1956. Oleneostrovski Mogilnik. Materialy i Issledovaniya po Arkheologii SSSR 47. Moscow: Nauka.

Indreko, R., 1948. Die mittlere Steinzeit in Estland. Stockholm: Wahlström \& Widstrand.

Korobkova, G. F., 1999. Narzędzia w pradziejach. Podstawy badania funkcji metoda traseologiczną. Toruń: Uniwersytet Mikołaja Kopernika.

Kozłowski, S. K., 1969. Z problematyki polskiego mezolitu (cz.10): kościane harpuny i ostrza mezolityczne. Światowit, 30, 135-152.

Langley, M. C., 2015. Investigating maintenance and discard behaviours for osseous projectile points: A middle to late Magdalenian (c. 19,00014,000 cal. BP) example. Journal of Anthropological Archaeology, 40, 340-360.

Langley, M.C., Pétillon, J. M., Christensen, M., 2016. Diversity and Evolution of Osseous Hunting Equipment During the Magdalenian (21,00014,000 cal BP). In: Langley M., eds. Osseous Projectile Weaponry (Vertebrate Paleobiology and Paleoanthropology Series). Dordrecht: Springer.

Legrand, A., 2007. Fabrication et utilisation de l'outillage en matières osseuses du Néolithique de Chypre: Khirokitia et Cap Andreas-Kastros. Oxford: Archaeopress (BAR International Series, 1678).

LeMoine, G., 1991. Experimental Analysis of the Manufacture and Use of Bone and Antler Tools among the Mackenzie Inuit. Alberta: University of Calgary.

Loze, I., 1988. Poselenija kamennogo veka Lubanskoj niziny. Mezolit, rannij i srednij neolit. Riga: Zinatne.

Lozovskaya, O., Lozovski, V., 2013. Barbed points from the site of Zamostje 2. In: Lozovski, V., Lozovskaya, O., Clemente-Conte, I., eds. Замостье 2. Озерное по- селение древних рыболовов эпохи мезолита-неолита в бассейне верхней Волги / Zamostje 2. Lake Settlement of the Mesolithic and Neolithic Fisherman in Upper Volga Region. St. Petersburg: Russian Academy of Science, 77-109. 
Luik, H., Piličiauskienè, G., 2016. Bone tools at the Neolithic sites of Šventoji, Lithuania: used materials and working methods. In: Vitezović, S., ed. Close to the bone: current studies in bone technologies. Belgrade: Institute of Archaeology, 188-200.

Müller, S., 1918. Stenalderens kunst i Danmark. København: C.A. Reitzel.

Newcomer, M. H., 1974. Study and replication of bone tools from Ksar Akil (Lebanon). World Archaeology, 6 (2), 138-154.

Orłowska, J., 2016. Reading osseous artefacts - an application of micro-wear analysis to experimentally worked bone materials. In: Vitezović, S., ed. Close to the bone: current studies in bone technologies. Belgrade: Institute of Archaeology, 236-247.

Orłowska, J., Osipowicz, G., 2018. Optic observations on osseous uniserial harpoon heads from the Polish Lowland as an element of discussion about their chronological affiliation. Quaternary International, 472, 3-12.

Osipowicz, G., 2010. Narzędzia krzemienne w epoce kamienia na ziemi chełmińskiej. Studium traseologiczne. Toruń: Uniwersytet Mikołaja Kopernika.

Osipowicz, G., Orłowska, J., Piličiauskas, G., Piličiauskienè, G., 2019. The story of one harpoon. An example of the reutilization of osseous projectile weapon in the Subneolithic Šventoji (Lithuania). In: García, M. A., García, E. A., eds. Spotlighting Bone Tools. Proceedings of the XII Meeting of the ICAZ Worked Bone Research Group in Granada. Cuadernos de Prehistoria y Arqueología de la Universidad de Granada number 29 (2019), 237-250.

Osipowicz, G., Orłowska, J., Piličiauskas, G., Piličiauskienè, G., Rannamäe, E., Cyrek, K., Sylwestrzak, M., 2020. Stone Age technologies and human behaviors as reflected in decoration of osseous artefacts from the northern part of East-Central Europe. Quaternary International (in press). https:// doi:10.1016/j.quaint.

Pétillon, J.-M., Plisson, H., Cattelain, P., 2016. Thirty Years of Experimental Research on the
Breakage Patterns of Stone Age Osseous Points. Overview, Methodological Problems and Current Perspectives. In: Iovita, R., Sano, K., eds. Multidisciplinary approaches to the study of Stone Age weaponry (=Vertebrate Paleobiology and Paleoanthropology Series). Dordrecht: Springer, 47-63.

Piličiauskas, G., 2016. Coastal Lithuania during the Neolithic. In: Zabiela, G., Baubonis, Z., Marcinkevičiūtè, E., eds. A Hundred Years of Archaeological Discoveries in Lithuania. Vilnius: Lietuvos archeologijos draugija, 64-77.

Piličiauskas, G., Mažeika, J., Gaidamavičius, A., Vaikutienè, G., Bitinas, A., Skuratovič, Ž., Stančikaitè, M., 2012. New archaeological, paleoenvironmental, and ${ }^{14} \mathrm{C}$ data from Šventoji Neolithic sites, NW Lithuania. Radiocarbon, 54(3-4), 1017-1031.

Piličiauskas, G., Heron, C., 2015. Aquatic radiocarbon reservoir offsets in the Southeastern Baltic. Radiocarbon, 57(4), 539-556.

Piličiauskas, G., Matiukas, A., Peseckas, K., Mažeika, J., Osipowicz, G., Piličiauskienè, G., Rannamäe, E., Pranckènaitè, E., Vengalis, R., Pilkauskas, M., 2020. Fishing history of the East Baltic during the Holocene according to underwater multiperiod riverine site Kaltanėnai, northeastern Lithuania. Archaeological and Anthropological Sciences (in press).

Płonka, T., 2017. Ornamented hunting weapons from the Late Palaeolithic in the Southern Baltic basin. In: Mărgărit, M., Boroneanț, A., eds. From hunter-gatherers to farmers: Human adaptations at the end of the Pleistocene and the first part of the Holocene: Papers in honour of Clive Bonsall. Romania: Editura Cetatea de Scaun, Targovişte, 217-228.

Płonka, T., 2019. Human representations in the Late Palaeolithic and Mesolithic art of north-western Europe. Quaternary International (in press). https:// doi:10.1016/j.quaint.

Płonka, T., Kowalski, K., 2017. Rusinowo. The Symbolic Culture of Foragers in the Late Palaeolithic and the Early Mesolithic. Wrocław: University of Wrocław Institute of Archaeology. 
Pokines, J. T., 1998. Experimental replication and use of Cantabrian lower Magdalenian antler projectile points. Journal of Archaeological Science, $25,875-886$.

Rimantienė, R., 2005. Die Steinzeitfischer an der Ostseelagune in Litauen. Forschungen in Šventoji und Bütingè. Vilnius: National Museum of Lithuania.

Rumiński, J., Osipowicz, G., 2014. Neolithic adhesive from a T-shaped ornamental element excavated at site 14 at Kowal, Kuyavia, central Poland. Archaeometry, 56, 129-144 .

Schwantes, G., 1939. Die Vorgeschichte SchleswigHolsteins (Stein- und Bronzezeit). In: Pault, V., Scheel, O., eds. Geschichte Schleswig-Holsteins, vol. 1. Neumünster: Karl Wachholtz Verlag.

Tomenchuk, J., Storck, P. L., 1997. Two newly recognized paleoindian tool types: single and doublescribe compass gravers and coring gravers. American Antiquity, 62(3), 508-522.

Verhart, L., 2000. The function of Mesolithic bone and antler points. Anthropologie et Préhistoire, 111, 114-23.

Zagorska, I., 1980. Das Frühmesolithikum in Lettland. Veröffentlichungen des Museums für Urund Frühgeschichte Potsdam, 14/15, 73-82.

Zagorska, I., 1993. The Mesolithic in Latvia. Acta Archaeologica, 63, 97-116.

Zagorska, I., Zagorskis, F., 1989. The bone and antler inventory from Zvejnieki II, Latvian SSR. In: Bonsall, C., ed. The Mesolithic in Europe: Papers
Presented at the 3rd International (Mesolithic) Symposium, Edinburgh 1985. Edinburgh: John Donald, 414-423.

Zhilin, M., 1998. Technology of the Manufacture of Mesolithic Bone Arrowheads on the Upper Volga. European Journal of Archaeology, 1/2, 149-175.

Zhilin, M., 2013. Traditions and Innovations in the Development of Bone Industry of the Butovo Culture. Stratum plus, 2013(1), 1-30.

Zhilin, M., 2014. Early Mesolithic hunting and fishing activities in Central Russia: A review of faunal and artefactual evidence from wetland sites. Journal of Wetland Archaeology, 14(1), 92-106.

Zhilin, M., 2015. Early Mesolithic bone arrowheads from the Upper Volga. Fennoscandia Archaeologica, 32, 35-54.

Zhilin, M., 2017a. Mesolithic bone arrowheads from Ivanovskoye 7 (central Russia): Technology of the manufacture and use-wear traces. Quaternary International, 427, 230-244.

Zhilin M., 2017b. Bone massive spear heads in the Mesolithic of Central Russia (Technological and functional study). Cuadernos de Prehistoria $y$ Arqueología de la Universidad de Granada, 27, 211-244.

Жилин, М., 1993. Костяное вооружение древнейшего населения Верхнего Поволжья. Москва: Русская равнина.

Жилин, М., 2001. Костяная индустрия мезолита тесной зоны Восточной Европь. Москва: yPCC. 


\section{KAULINIAI ANTGALIAI IR ŽEBERKLAI LIETUVOS PAJŪRIO ŠVENTOSIOS SUBNEOLITINĖSE GYVENVIETĖSE: GAMYBA IR NAUDOJIMAS PIRMŲJŲ TRASOLOGINIŲ TYRIMŲ DUOMENIMIS}

Grzegorz Osipowicz, Justyna Orłowska, Gytis Piličiauskas, Giedrè Piličiauskienè, Mariusz Bosiak

\section{Santrauka}

Kauliniai strèlių ir žeberklų antgaliai sudarè didelę akmens amžiaus žvejų ir medžiotojų įrangos dalį. Jų tyrimai atliekami nuo seno ir yra labai svarbūs tyrinejjant priešistorines bendruomenes. Kaulinių antgalių buvo aptikta ir Šventosios (ŠV Lietuva) akmens amžiaus gyvenviečių tyrimų metu, šių dirbinių rasta subneolitu ir neolitu datuojamuose sluoksniuose.

Kelios dešimtys kaulinių dirbinių, rastų Šventosios 1, 3, 4, 6 ir 23 gyvenvietèse, gali būti klasifikuojami kaip strèlių, iečių ir žeberklų antgaliai. Šiame straipsnyje pateikiama 17 tokių dirbinių, datuojamų 3500-2700 cal BC, t. y. subneolitu, mikroskopinių tyrimų rezultatai. Visi tirti dirbiniai yra saugomi Lietuvos nacionaliniame muziejuje. Iš tirtų dirbinių tiktai vienas žeberklas, rastas Šventosios 6 gyvenvieteje, yra datuotas tiesiogiai radiokarboniniu būdu (3627-3363 cal вC). Kiti dirbinai datuoti pagal gyvenviečių stratigrafiją ir kitų jose rastų radinių ar struktūrų radiokarbonines datas. Mūsų tirti dirbiniai iš Šventosios 1 ir 2 gyvenviečių buvo rasti jų apatiniuose horizontuose su subneolitine keramika. Šventosios 3 ir 23 gyvenvietèse apskritai rasta tiktai subneolitinio laikotarpio keramikos, tad galima teigti, kad kauliniai radiniai taip pat turètų būti datuojami šiuo laikotarpiu. Šventosios 6 gyvenvieteje subneolito ir neolito radiniai randami susimaišę tame pačiame sluoksnyje. Tačiau labiausiai tikètina, kad tirti kauliniai radiniai priklauso būtent subneolito gyvenvietei, mat šio laikotarpio radiniai yra vyraujantys.

Pagrindinis šios studijos tikslas buvo nustatyti, kaip buvo gaminami tirti antgaliai ir žeberklai, rekonstruoti jų gamybos operacijų seką ir pabandyti atsakyti i klausimą, kaip jie buvo naudojami.

Trasologiniai tyrimai parodè, kaip buvo gaminti kauliniai antgaliai. Jų forma buvo išgaunama naudojant tris pagrindines apdirbimo technikas - gremžimą, drožimą ir šlifavimą. Tačiau šios technikos nebuvo taikomos visam dirbiniui, o naudotos tik tam tikroms jo dalims formuoti. Atskirai buvo formuojama antgalio viršūnè, apdirbamas antgalio apatinès dalies paviršius, ypač kaulo laužimo, skèlimo vietose, kartais specialiai formuotas pagrindas.

Prastas žeberklų išlikimas ir fragmentiškumas tiktai keletu atvejų leido atlikti detalesnę jų technologinę analizę. Tyrimai parodè, kad paskutinè žeberklų apdirbimo fazè nesiskyrè nuo antgalių apdirbimo. Pagrindiniai gamybos žingsniai buvo viršūnès formavimas gremžiant, kaulo nulaužimas apatinejje dirbinio dalyje, užbarzdų formavimas, vienašonių žeberklų atveju - priešais užbarzdas esančio dirbinio šono formavimas. Natūraliai iškilęs kaulo paviršius šalia žeberklų viršūnių faktiškai nebuvo apdirbamas. Kartais gamybos pabaigoje žeberklas buvo nušlifuojamas. Užbarzdos paprastai formuotos keliais būdais iš abiejų pusių pjaunant, gremžiant ir drožiant. Vienu atveju užbarzdos formuotos iškalant/ išdrožiant. Vieno žeberklo paviršius puoštas akučių ornamentu, kuris greičiausiai išgautas metaliniu įrankiu (Osipowicz et al. 2020). SEM-EDX tyrimai parode, kad akutès dar buvo ir inkrustuotos mase iš pelenų bei molio.

Deja, trasologinių tyrimų rezultatai neleidžia nustatyti, kokiu tikslu naudoti dirbiniai, kurie dèl savo formos yra įvardijami kaip antgaliai. Gali būti, 
kad daugeliu atvejų jiems priskiriama funkcija nèra teisinga. Toliau šioje srityje vykdomi tyrimai turètų būti itin svarbūs atskleidžiant kiekvienos iš Šventosios gyvenviečių funkciją ir specifiką. Nors Šventosios gyvenvietèse aptiktas nedidelis kaulinių antgalių skaičius, tačiau morfologiškai jie labai ịvairūs, be to, kiekvienoje gyvenvietėje aptikta įvairių tipų dirbinių. Šie faktai kol kas neleidžia daryti išvadų apie kiekvienos iš gyvenviečių funkciją.

Tai pirmieji tokie išsamūs Šventosios gyvenvietėse aptiktų kaulinių antgalių ir žeberklų trasologiniai tyrimai. Jie atskleidè, kad, gaminant šiuos skirtingų tipų dirbinius, buvo naudotos labai panašios gamybos technologijos, o jų gamyboje labai ryškus minimalizmas, t. y. buvo atliekamos tiktai pačios būtiniausios operacijos, ịdedamos minimalios pastangos. Tai leistų teigti, kad dauguma ištirtų dirbinių yra buityje ir kasdieneje veikloje naudoti įrankiai, nesusiję su kulto apeigoms, mat tokio tipo dirbinių gamyboje greičiausiai daugiau dèmesio būtų skirta ìvairioms detalèms.

\section{ILIUSTRACIJŲ SĄRAŠAS}

1 pav. Šventosios gyvenviečių situacija. G. Piličiausko brëž.
2 pav. Tirti antgaliai ir žeberklai iš Šventosios 1 ir 3 gyvenviečių. J. Orlowskos nuotr.

3 pav. Tirti antgaliai ir žeberklai iš Šventosios 4, 6 ir 23 gyvenviečių. J. Orlowskos nuotr.

4 pav. Technologinès žymès, užfiksuotos ant tyrinètų Šventosios gyvenviečių dirbinių. G. Osipowizciaus nuotr.

5 pav. Technologinès žymès, užfiksuotos ant tyrinètų Šventosios gyvenviečių dirbinių. G. Osipowizciaus nuotr.

6 pav. Funkcinès žymès, užfiksuotos ant tyrinètų Šventosios gyvenviečių dirbinių. G. Osipowizciaus nuotr.

7 pav. Akutėmis puošto žeberklo (EM2138:666) ornamento užpildo mèginio SEM-EDX analizès rezultatai (žr. 3 lent.).

\section{LENTELIŲ SĄRAŠAS}

1 lentelè. Tirtų dirbinių kontekstinè informacija ir aprašymas.

2 lentelè. Pagrindiniai trasologinių tyrimų rezultatai.

3 lentelè. Akutėmis puošto žeberklo (EM2138:666) ornamento užpildo mėginio SEM-EDX analizès rezultatai. 